\title{
Middle Ordovician Drepanoistodus (Vertebrata, Conodonta) from Baltica, with description of three new species
}

\author{
Jan Audun RASMUSSEN ${ }^{\circledR 1, *}$, Mats E. ERIKSSON ${ }^{\circledR 2}$ \& Anders LINDSKOG ${ }^{\circledR 3}$ \\ ${ }^{1}$ Museum Mors, Skarrehagevej 8, DK-7900 Nykøbing Mors, Denmark. \\ ${ }^{1}$ Natural History Museum of Denmark, University of Copenhagen, Øster Voldgade 5-7, \\ DK-1350 Copenhagen K, Denmark. \\ ${ }^{2,3}$ Department of Geology, Lund University, Sölvegatan 12, S-22362 Lund, Sweden. \\ *Corresponding author: jan.rasmussen@museummors.dk \\ ${ }^{2}$ Email: mats.eriksson@geol.lu.se \\ ${ }^{3}$ Email: anders.lindskog@geol.lu.se \\ ${ }^{1}$ urn:lsid:zoobank.org:author:1FC1FE29-5088-4673-A58D-560360917034 \\ ${ }^{2}$ urn:lsid:zoobank.org:author:603567D0-6505-4DBF-9C41-3DE1FC7A2112 \\ ${ }^{3}$ urn:lsid:zoobank.org:author:0050F75E-13C1-48B3-B5D8-E3012D804F78
}

\begin{abstract}
Drepanoistodus basiovalis (Sergeeva, 1963) is a common conodont species in Middle Ordovician strata of Baltica. For many years it has been widely accepted that the species encompasses a wide range of morphological plasticity. Hence, several different morphotypes that significantly deviate from the holotype have nonetheless been included in the broad species concept. In this study, we performed a detailed taxonomical study on 112 predominantly well-preserved specimens (geniculate elements) from the St. Petersburg region of Russia; 37 of these were selected for morphometric analyses together with 21 wellillustrated specimens from the published literature. The results demonstrate that, among the morphotypes that share some characteristics with $D$. basiovalis sensu lato, at least five species can be readily distinguished. Hence, three new species - Drepanoistodus iommii sp. nov., D. svendi sp. nov. and D. viirae sp. nov. are here added to the previously known D. basiovalis and D. contractus (Lindström, 1955). In addition, some specimens were left under open nomenclature and assigned to Drepanoistodus aff. basiovalis and D. cf. suberectus (Branson \& Mehl, 1933). In order to objectively compare the Drepanoistodus taxa and test the validity of the new species, we performed a Principal Component Analysis combined with nonparametric (PERMANOVA) tests based on 21 morphological characters.
\end{abstract}

Keywords. Conodont, Drepanoistodus, new species, Ordovician, Baltica.

Rasmussen J.A., Eriksson M.E. \& Lindskog A. 2021. Middle Ordovician Drepanoistodus (Vertebrata, Conodonta) from Baltica, with description of three new species. European Journal of Taxonomy 774: 106-134.

https://doi.org/10.5852/ejt.2021.774.1533

\section{Introduction}

Conodonts are generally interpreted as an extinct clade of marine vertebrates (Aldridge et al. 1993; Donoghue et al. 2000; Murdock et al. 2013), although also other hypotheses regarding their affinity 
have been suggested (Turner et al. 2010). These primitive 'fish' first appeared in the Late Cambrian and went extinct in the Late Triassic. Whereas body fossils are very rare, the microscopic tooth-like elements (known as conodont elements) are composed of calcium phosphate and have great preservation potential. Therefore, these microfossils can be extracted in large quantities from calcareous, sedimentary rocks, and have proven widely useful, e.g., for biostratigraphy, palaeogeography, palaeobathymetry, and assessing thermal maturity (by means of colour alteration index; CAI).

Conodont microfossils have been known for more than 160 years with the first description of these phosphatic elements published being that of Pander (1856), who based his study on material from the St. Petersburg region, Russia. Since then, several studies have dealt with Ordovician conodonts from this area (e.g., Sergeeva 1962, 1963, 1974; Bergström 1988; Tolmacheva 2001; Tolmacheva et al. 2001, 2003a, 2003b). The present study follows this research tradition and is based on conodonts from the Lynna River section of Russia (Fig. 1).

Ever since the first multi-element reconstruction of the conodont genus Drepanoistodus Lindström, 1971 was made by Lindström (1971), it has been generally accepted that Drepanoistodus basiovalis (Sergeeva, 1963), a common species in the Middle Ordovician of Baltoscandia, includes quite a wide range of different morphotypes. Whereas some of these morphotypes were subsequently distinguished as distinct species, e.g., Drepanoistodus contractus (Lindström, 1955) (see Stouge \& Bagnoli 1990), most have been tentatively assigned to Drepanoistodus under open nomenclature, as D. cf. basiovalis and D. aff. basiovalis (e.g., Rasmussen 2001; Mellgren \& Eriksson 2010; Lindskog et al. 2020), or accepted as morphological variations fitting into the broad species concept of $D$. basiovalis. Originally, Sergeeva (1963) based the characterisation of the new species Oistodus basiovalis on geniculate elements from the Volkhovian and Kundan regional stages (Dapingian to middle Darriwilian global stages) of the St. Petersburg region. The holotype was recovered from Volkhovian strata. The two original D. basiovalis specimens figured by Sergeeva (1963) were incorporated in the analyses performed herein, alongside other elements assigned to $D$. basiovalis, $D$. cf. basiovalis or $D$. aff. basiovalis by various authors.

In this study we assess $D$. basiovalis-like specimens from Dapingian through middle Darriwilian (Middle Ordovician) strata of the Lynna River in the St. Petersburg region, Russia, and demonstrate that these unarguably comprise a collection of separate species, which are readily distinguished based

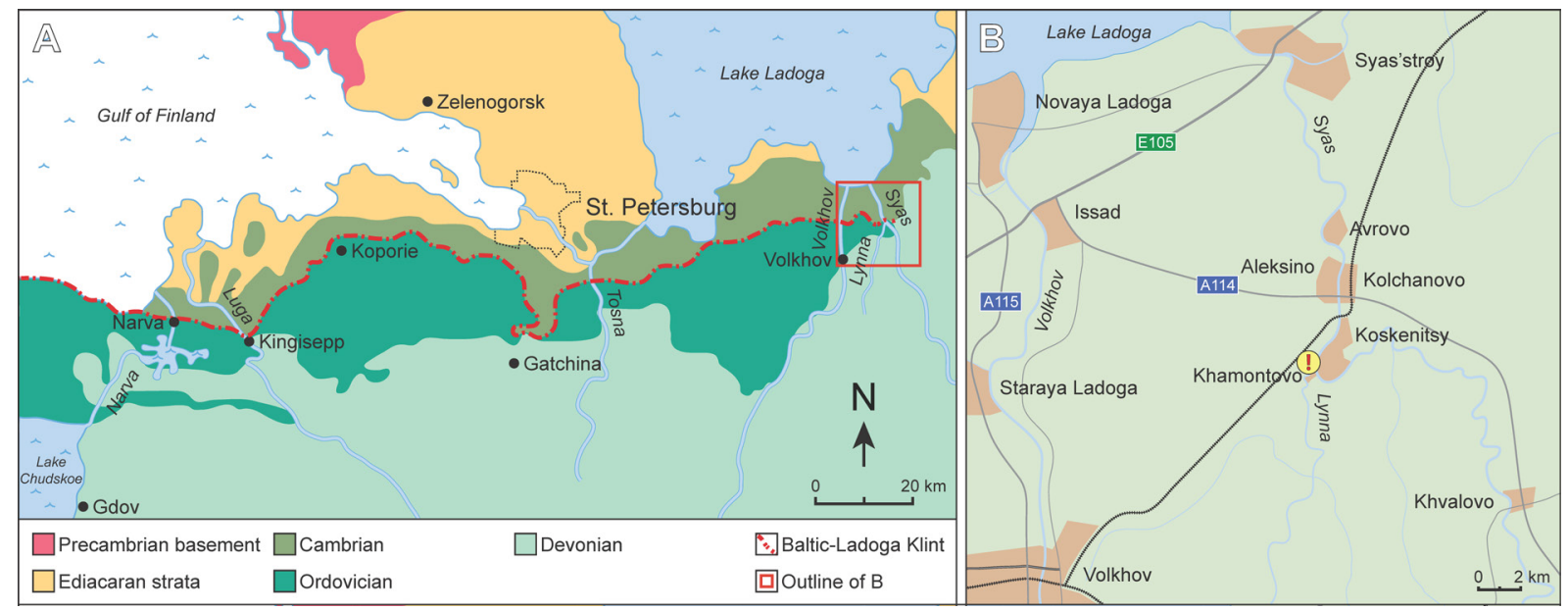

Fig. 1. A. Map of the St. Petersburg region, Russia, with the distribution of rocks. The red rectangle shows the outline of the map area enlarged in B. B. Map of the Lynna River study locality and its surroundings. Figure modified from Lindskog et al. (2020, and references therein). 
on morphological characters of the geniculate elements. The validity of all taxa has been tested by use of Principal Component Analysis followed by the non-parametric PERMANOVA similarity test comprising 21 morphological characters.

\section{Geological setting}

The St. Petersburg region of Russia has an extensive history of geological exploration, and the Ordovician strata have been well studied (Fig. 1; e.g., Pander 1830; Schmidt 1882; Lamansky 1905; Raymond 1916; Sergeeva 1962; Ivantsov 2003; Dronov \& Mikuláś 2010; Rasmussen \& Harper 2008; Lindskog et al. 2020). During the Ordovician this region formed part of the palaeocontinent Baltica, at the time situated in the southern hemisphere and moving northwards (Cocks \& Torsvik 2006). Baltica was largely covered by a shallow sea, in which laterally extensive sedimentary strata were being deposited (e.g., Männil 1966; Lindström 1971; Jaanusson 1973). Today, the rocks of the St. Petersburg region form part of the natural escarpment known as the Baltic-Ladoga Klint (Fig. 1; Dronov \& Mikulaš 2010). The regional Ordovician succession is ca 100-200 m thick and composed predominantly of carbonate rocks. East of the city of St. Petersburg, several natural exposures have been cut into the Palaeozoic rocks by rivers that drain into Lake Ladoga, providing ample opportunity for quarrying as well as scientific studies (e.g., Popov 1997; Dronov \& Mikulaš 2010).

South-southwest of the village of Kolchanovo, ca $150 \mathrm{~km}$ east of St. Petersburg, Middle Ordovician sedimentary rocks crop out along the Lynna River. For this study, we sampled an exposure in the valley close to the mouth of the river, where it drains into the Syas River (Fig. 1; WGS 84 coordinates $60^{\circ} 00^{\prime} 39^{\prime \prime} \mathrm{N}, 32^{\circ} 33^{\prime} 49^{\prime \prime}$ E). The relatively expanded local succession, comprising the upper Volkhov, Lynna, Sillaoru, and lower Obukhovo formations, is approximately $10 \mathrm{~m}$ thick and mainly composed of alternating limestone and variably silty-sandy marl (e.g., Lindskog et al. 2020). Chronostratigraphically, it spans the uppermost middle Volkhovian to lowermost upper Kundan regional stages, which corresponds approximately to the uppermost Dapingian through lowermost middle Darriwilian global stages (Fig. 2).

For additional detailed information on the geology and (bio)stratigraphy of the Lynna River section, readers are referred to the recent study by Lindskog et al. (2020).

\section{Material and methods}

For a study on carbonate sedimentology and conodont stratigraphy at Lynna River (see Lindskog et al. 2020), 22 samples were treated with buffered acetic acid for the retrieval of microfossils according to standard procedures (e.g., Jeppsson et al. 1999). These collections formed the basis also for the present study. After sieving of the acid-insoluble residues, conodont elements were electrostatically handpicked from the $>63 \mu \mathrm{m}$ heavy fractions. In total, the collections comprise tens of thousands of conodont elements, most of which are well to excellently preserved. A consistent colour alteration index (CAI) of ca 1 indicates insignificant heating of the local rocks (cf. Epstein et al. 1977).

All conodont specimens derive from the Volkhov, Lynna, Sillaoru and Obukhovo formations at Lynna River (Fig. 2). In terms of conodont biostratigraphy, the sampled strata span the Lenodus antivariabilis Zone to the base of the Lenodus pseudoplanus Zone (see Lindskog et al. 2020), which correlate with the upper Volkhovian and Kundan regional stages, and the Darriwilian global Stage (Dw1-lower Dw2 stage slices; Ivantsov 2003; Bergström et al. 2009; Lindskog et al. 2020).

Photographs of conodont elements were taken with an Olympus SC30 digital camera attached to an Olympus SZX16 light microscope. All images were subsequently processed and stacked to increase focal depth, using cellSens software. Lighting conditions and magnification were kept at identical settings for all specimens. 


\section{Material repository}

All sample materials are stored at the Department of Geology, Lund University, Sweden, where the 13 figured conodonts belong to the type collection and have repository numbers LO (for Lund Original) followed by five digits and a t for "type specimen" and capital $\mathrm{T}$ for holotype.

\section{Morphometric analyses}

Principal Component Analysis (PCA) helps to identify patterns in large datasets with many variables, and to objectively highlight similarities and differences. Hence, PCA plots concentrate variance into relatively few axes compared to the high dimensionality (many variables) of the original data, and thereby aid in distinguishing between different morphotype groupings. Herein, we used this method to visualize the most typical characters in each species and also to show which species are most morphologically similar. PCA was first described by Pearson (1901) and has since then been used in numerous morphometrical/ phenetic taxonomical studies. We refer readers to e.g., Davis (1986) and Hammer \& Harper (2006) for more detailed descriptions of PCA, the latter including a palaeontological perspective. All statistical analyses and initial plots were performed using the free PAST software package (Hammer et al. 2001).

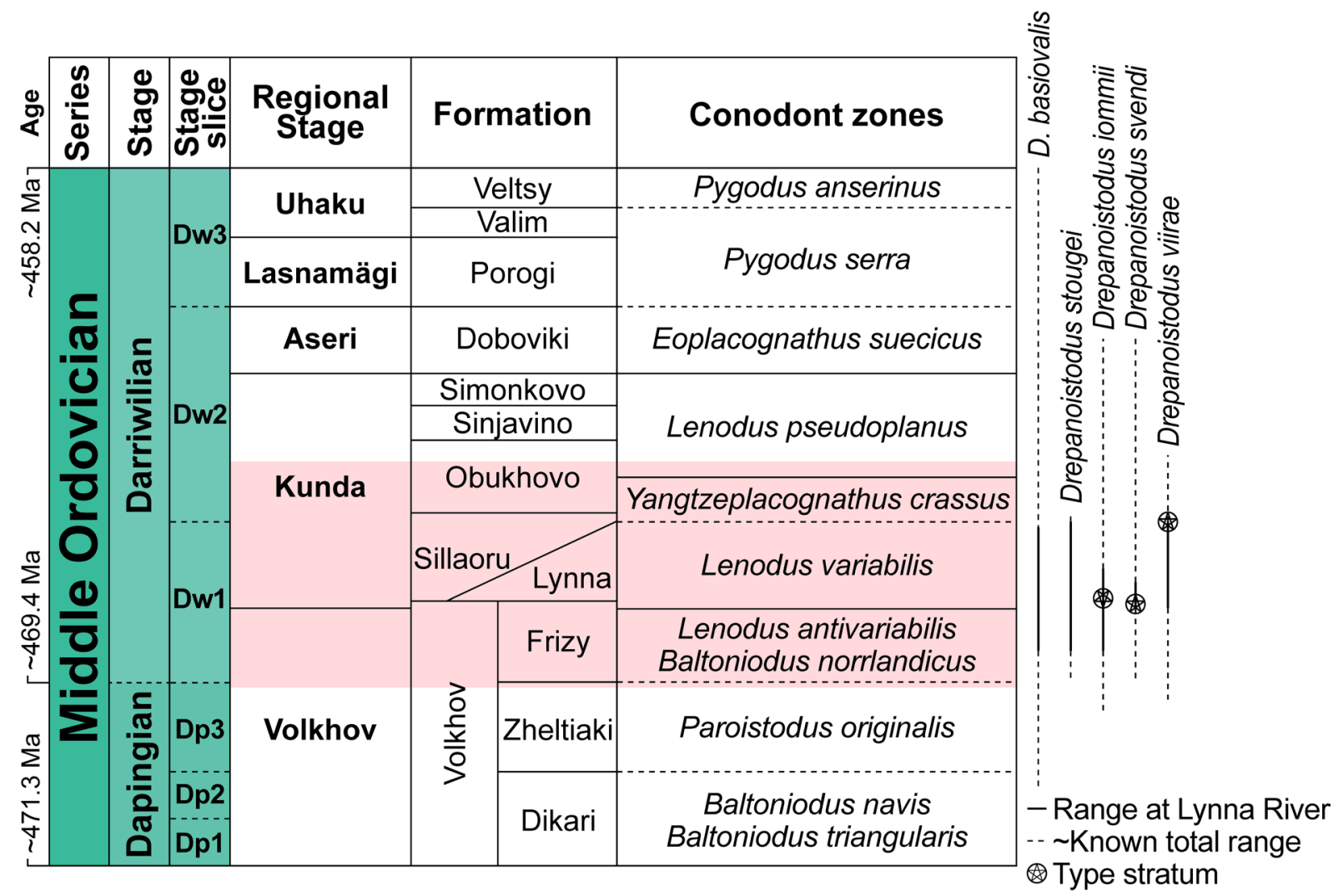

Fig. 2. The Middle Ordovician stratigraphy of the St. Petersburg region with Baltoscandian and global stratigraphy for comparison (modified from Lindskog et al. 2020, and references therein; additions after Pärnaste et al. 2013; Bauert et al. 2014; Gradstein et al. 2020). The pink area indicates the approximate stratigraphic range of the outcrop at the Lynna River, with ranges of selected Drepanoistodus species indicated. For more detailed information on the local conodont biostratigraphy and ranges of individual species, see Lindskog et al. (2020: fig. 6). 
The PCA approach used herein was based on 21 unweighted morphometric characters from the geniculate element in Drepanoistodus (see below in "Species characters and coding" and Fig. 3 for explanation of the 19 binary (presence/absence) and two numerical characters included). All selected morphological characters were observable in 58 of the examined specimens of Drepanoistodus, making them applicable for the PCA and statistical tests (Table 1). In the present work, we have reduced the visual result to two dimensions, where only the two most significant principal axes were plotted (Fig. 4). Because the plot involves morphological characters of different types (presence/absence, measured angle, and distance ratio), the correlation coefficient matrix was selected instead of the more common variance-covariance matrix, which means that variables are centred and standardized at the same time. The first principal axis (PC 1, the horizontal axis) accounts for $18.4 \%$ of the total data variance and the second principal axis (PC 2, the vertical axis) accounts for $16.1 \%$ of the variance.

The result of the PCA is visualized in a so-called biplot (Gower \& Hand 1996), where both objects (individual geniculate conodont elements) and variables (selected morphologic characters) are presented simultaneously. The variables are shown in Fig. 4 as blue lines (vectors), where both the direction and length of the vectors are important. For example, the vectors representing $b / c$ (ratio

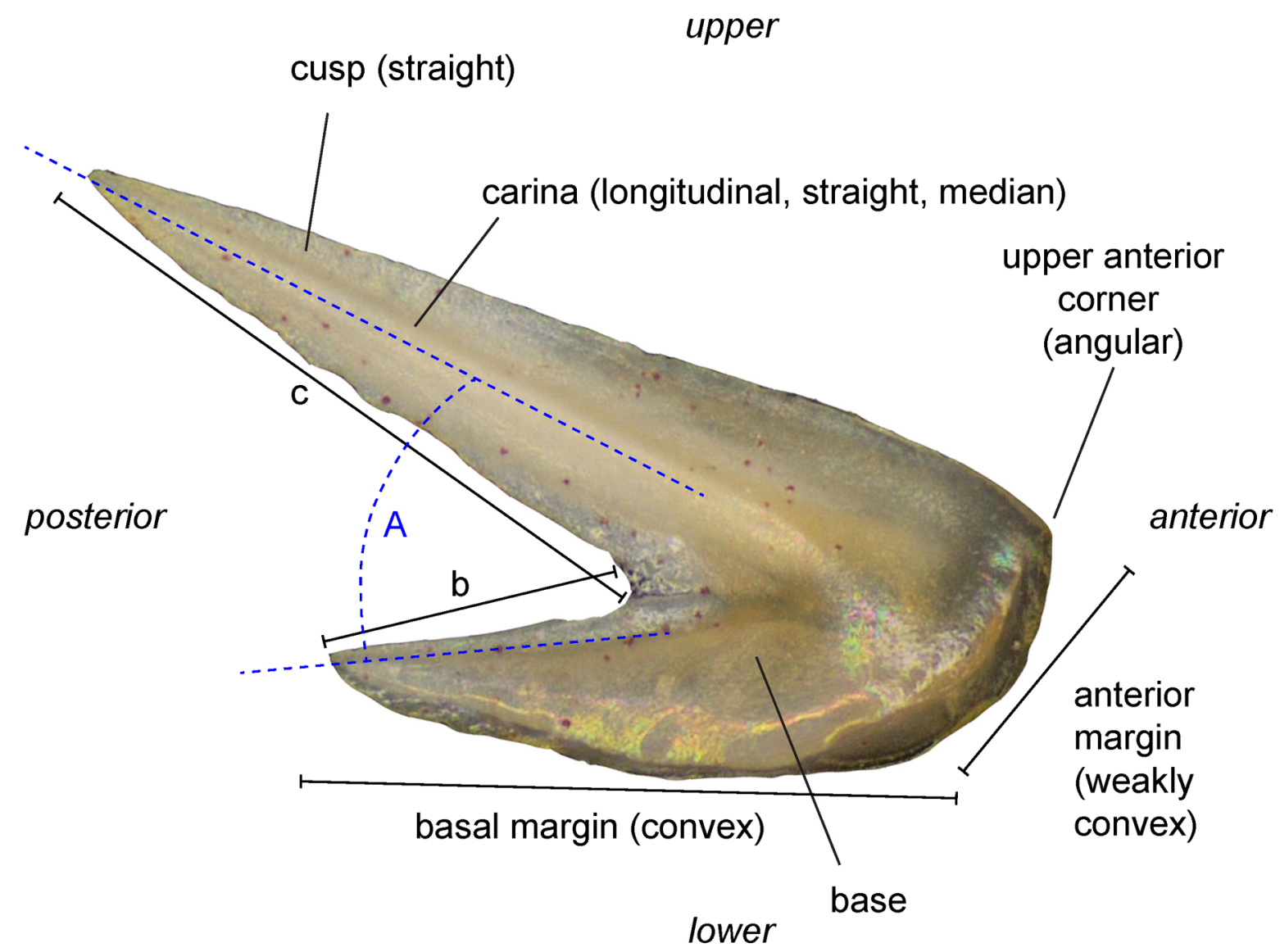

Fig. 3. Geniculate Drepanoistodus basiovalis (Sergeeva, 1963) element demonstrating the essential morphological characteristics utilized in the present study. Two characters were measured quantitatively: Angle A between the median line (usually carina) of the cusp and the lower margin of the keel situated on the upper margin of the cusp (A); and the b/c ratio, which is the ratio between the length of the upper margin of the base (b) and the length of the free cusp (c). 
Table 1 (continued on next page). Specimens included in the Principal Component Analysis and PERMANOVA test.

\begin{tabular}{ll}
\hline Abbreviation & Original species name and reference \\
\hline
\end{tabular}

Drepanoistodus basiovalis (Sergeeva, 1963)

DbasSe63-6Ht Oistodus basiovalis, holotype, Sergeeva, 1963: pl. 7 fig. 6; text-fig. 3

DbasSe63-7 Oistodus basiovalis, Sergeeva, 1963: pl. 7 fig. 7; text-fig. 3)

Dbasla

Dbas $1 b$

Drepanoistodus basiovalis (Sergeeva, 1963), sample LY12-9, \#a

Dbas1c

Drepanoistodus basiovalis (Sergeeva, 1963), sample LY12-9, \#b

Dbas1d

Drepanoistodus basiovalis (Sergeeva, 1963), sample LY12-9, \#c

Dbas2a

Drepanoistodus basiovalis (Sergeeva, 1963), sample LY12-9, LO 12477t

Dbas2c

Dbas3a

Dbas5a

Dbas5c

Dbas7a

Dbas7c

Dbas7d

Drepanoistodus basiovalis (Sergeeva, 1963), sample LY12-5, \#a

Drepanoistodus basiovalis (Sergeeva, 1963), sample LY12-5, \#c

Drepanoistodus basiovalis (Sergeeva, 1963), sample LY12-3, \#a

Drepanoistodus basiovalis (Sergeeva, 1963), sample LY12-1, \#a

Drepanoistodus basiovalis (Sergeeva, 1963), sample LY12-1, \#c

Drepanoistodus basiovalis (Sergeeva, 1963), sample LY12-14, \#a

Drepanoistodus basiovalis (Sergeeva, 1963), sample LY12-14, \#c

Dbas8a

Dbas10a

Dbas10c

Dbas11a

DbasSB90-22

DbasSB90-23

DbasSB90-24

DbasR91-L

DbasL94-30

Drepanoistodus basiovalis (Sergeeva, 1963), sample LY12-14, \#d

Drepanoistodus basiovalis (Sergeeva, 1963), sample LY12-16, LO 12476t

Drepanoistodus basiovalis (Sergeeva, 1963), sample LY12-21, \#a

Drepanoistodus basiovalis (Sergeeva, 1963), sample LY12-21, \#c

Drepanoistodus basiovalis (Sergeeva, 1963), sample LY12-21b, LO 12478 t

DbasL06-N

Drepanoistodus basiovalis (Sergeeva, 1963), Stouge \& Bagnoli 1990: pl. 5 fig. 22 Drepanoistodus basiovalis (Sergeeva, 1963), Stouge \& Bagnoli 1990: pl. 5 fig. 23 Drepanoistodus basiovalis (Sergeeva, 1963), Stouge \& Bagnoli 1990: pl. 5 fig. 24 Drepanoistodus basiovalis (Sergeeva, 1963), Rasmussen 1991: fig. 61 Drepanoistodus basiovalis (Sergeeva, 1963), Löfgren 1994: fig. 6.30 Drepanoistodus basiovalis (Sergeeva, 1963), Löfgren 2006: fig. 3n

Drepanoistodus iommii sp. nov.
Diom8a-Ht
Drepanoistodus iommii sp. nov, holotype, sample LY12-16, LO 12479 T
Diom1a
Drepanoistodus iommii sp. nov, sample LY12-9, \#a
Diom3a
Drepanoistodus iommii sp. nov, sample LY12-3, LO 12481t
Diom 4 a
Drepanoistodus iommii sp. nov, sample LY12-2, \#a
Diom $4 b$
Drepanoistodus iommii sp. nov, sample LY12-2, \#b
Diom4c
Drepanoistodus iommii sp. nov, sample LY12-2, \#c
Diom11a
Drepanoistodus iommii sp. nov, sample LY12-21, \#a
Diom11b
Drepanoistodus iommii sp. nov, sample LY12-21, LO 12480t)
DiomME10-M
Drepanoistodus aff. basiovalis (Sergeeva, 1963), Mellgren \& Eriksson 2010: fig. 7m
DiomM12-E
Drepanoistodus cf. basiovalis (Sergeeva, 1963), Mellgren et al. 2012: fig. 5e

Drepanoistodus svendi sp. nov.
Dsve7b-Ht
Dsve6a
Drepanoistodus svendi sp. nov., holotype, sample LY12-14, LO 12483 T
DsveR01-17
Drepanoistodus svendi $\mathrm{sp}$. nov, sample LY12-13, LO 12482t
DsveM12-U
Drepanoistodus aff. basiovalis (Sergeeva, 1963), Rasmussen 2001: pl. 5 fig. 17
Drepanoistodus aff. basiovalis (Sergeeva, 1963), Mellgren et al. 2012: fig. 7u 
Table 1 (continued). Specimens included in the Principal Component Analysis and PERMANOVA test.

\begin{tabular}{ll}
\hline Abbreviation & Original species name and reference \\
\hline \multicolumn{2}{l}{ Drepanoistodus viirae sp. nov. } \\
Dvii16b-Ht & Drepanoistodus viirae sp. nov., holotype, sample LY12-31, LO 12484T \\
Dvii6a & Drepanoistodus viirae sp. nov., sample LY12-13, \#a \\
Dvii15a & Drepanoistodus viirae sp. nov., sample LY12-30, \#a \\
DviiL00-P & Drepanoistodus basiovalis (Sergeeva, 1963), Löfgren 2000b: fig. 4p \\
DviiME10-F & Drepanoistodus aff. suberectus (Branson \& Mehl, 1933), Mellgren \& Eriksson 2010: fig. 7f \\
DviiLi20-V & Drepanoistodus basiovalis (Sergeeva, 1963), Lindskog et al. 2020: fig. 7v
\end{tabular}

Drepanoistodus aff. basiovalis (Sergeeva, 1963)

$\begin{array}{ll}\text { Daffbas1a } & \text { Drepanoistodus aff. basiovalis (Sergeeva, 1963), sample LY12-9, LO 12486t } \\ \text { Daffbas1b } & \text { Drepanoistodus aff. basiovalis (Sergeeva, 1963), sample LY12-9, \#b } \\ \text { Daffbas2a } & \text { Drepanoistodus aff. basiovalis (Sergeeva, 1963), sample LY12-5, \#a } \\ \text { Daffbas6a } & \text { Drepanoistodus aff. basiovalis (Sergeeva, 1963), sample LY12-13, \#a } \\ \text { Daffbas7a } & \text { Drepanoistodus aff. basiovalis (Sergeeva, 1963), sample LY12-14, \#a } \\ \text { DaffbasME10-D } & \text { Drepanoistodus cf. basiovalis (Sergeeva, 1963), Mellgren \& Eriksson 2010: fig. 7d } \\ \text { DaffbasME10-H } & \text { Drepanoistodus aff. basiovalis (Sergeeva, 1963), Mellgren \& Eriksson 2010: fig. 7h }\end{array}$

Drepanoistodus cf. suberectus (Branson \& Mehl, 1933)

Dcfsub20a Drepanoistodus cf. suberectus (Branson \& Mehl, 1933), sample LY14-2, LO 12488t

Dcfsub22a Drepanoistodus cf. suberectus (Branson \& Mehl, 1933), sample LY14-5, \#a

Drepanoistodus balticus (Löfgren, 2006)

DbalL06B-Ht Venoistodus balticus, holotype, Löfgren, 2006: fig. 3b

DbalL06-E Venoistodus balticus, Löfgren, 2006: fig. 3e

DbalL06-L Venoistodus balticus, Löfgren, 2006: fig. 31

Drepanoistodus stougei Rasmussen, 1991

DstoR91-Ht Drepanoistodus stougei, holotype, Rasmussen, 1991: fig. 6j

Dsto6b-typical Drepanoistodus stougei Rasmussen, sample LY12-13, LO 12487t

between the free upper margin and the free cusp) and BaMaStra (Basal margin straight) are relatively long and point towards the population of $D$. iommii sp. nov. in the upper, right-hand corner of the plot. This means that the D. iommii sp. nov. geniculate elements have a high $\mathrm{b} / \mathrm{c}$ value and a dominantly straight basal margin. By contrast, specimens plotting in the opposite (lower left-hand) part of the diagram never or rarely show such features (in this case Drepanoistodus viirae sp. nov. plots in the lower left quadrangle).

The final step of the multivariate analysis was to test if the three new species are similar to (or different from) D. basiovalis based on the 21 selected characters. To do this, we formulated and tested three null hypotheses: Drepanoistodus basiovalis is similar to one of three new species $D$. iommii sp. nov., $D$. svendi sp. nov. and/or D. viirae sp. nov. For this purpose, we performed the multivariate (analysis of variance) non-parametric test PERMANOVA (= NPMANOVA), which was based on the Euclidian 


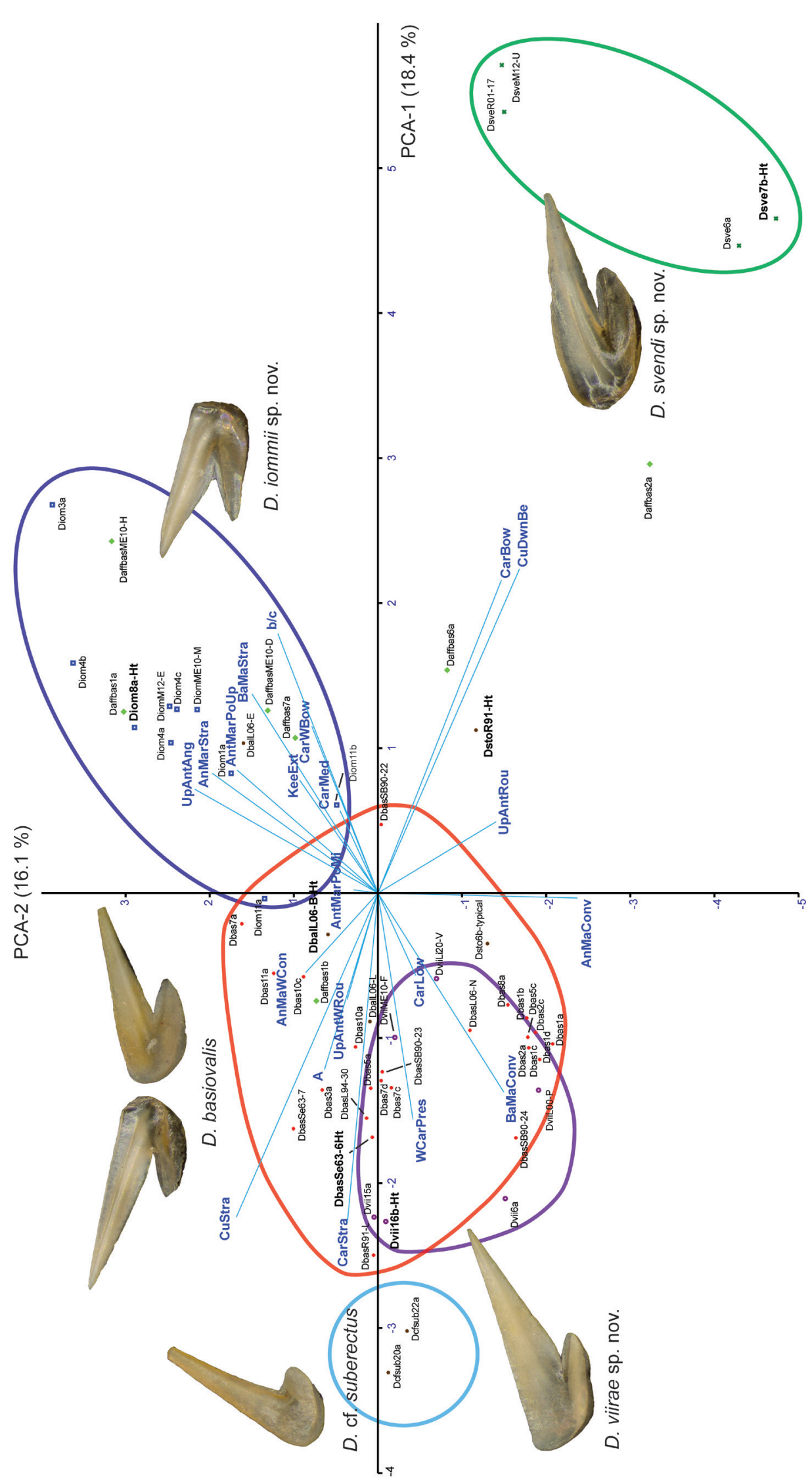

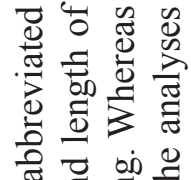

बै छ

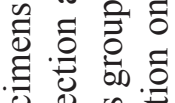

氙

ज正

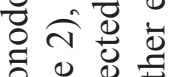

웡 $\frac{0}{0}$

就苍

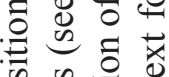

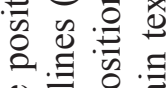

‡ั

on 0

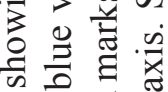

궁흉

뭉

离芯壱

造응

후월응

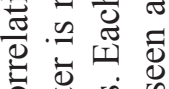

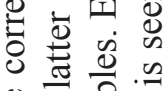

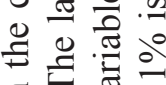

б 료

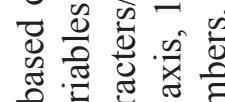

휴 흉

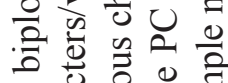

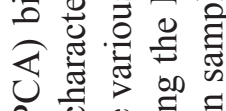

능 \&

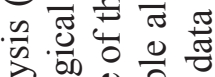

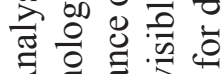

穴严里

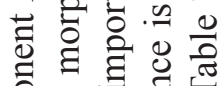

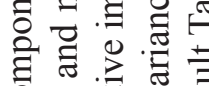

ปิ่

픙 웡

证焉

记

+ن

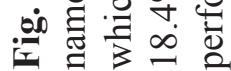


distance coefficient, to assess equality of the calculated centroids (means) of the four species groupings compared (see e.g., Hammer \& Harper 2006); the preferable parametric Hotelling's $\mathrm{T}^{2}$ test was not applicable, as our multivariate dataset is non-normally distributed (and, furthermore, relatively small). Commonly, only the Principal Components (axis), which represent more than $5 \%$ of the total variance in the PCA plot, are tested and interpreted. In this case, the first seven axes contributed with more than $5 \%$ of the variance each and were subsequently used in the PERMANOVA test. Because all the test probabilities are below 0.05 (Fig. 5A), the three null hypotheses are rejected, and there is no statistical evidence from the test that the groups (species) are objectively similar. We refer readers to Marrama \& Kriwet (2017) for a detailed explanation of the combined PCA and PERMANOVA methods used for taxonomic identifications.

\section{A. Multivariate one-way PERMANOVA test}

\begin{tabular}{|l|r|r|r|r|}
\hline \multicolumn{2}{|c|}{ D. basiovalis } & D. iommii & D. svendi & D. viirae \\
\hline D. basiovalis & & 0.0001 & 0.0001 & 0.0080 \\
\hline D. iommii & 0.0001 & & 0.0011 & 0.0003 \\
\hline D. svendi & 0.0001 & 0.0011 & & 0.0057 \\
\hline D. viirae & 0.0080 & 0.0003 & 0.0057 & \\
\hline
\end{tabular}

\section{B. Univariate statistics}

\begin{tabular}{|lrr|lrr|}
\hline D. basiovalis & A & b/c & D. svendi & A & b/c \\
\hline N & 24 & 23 & N & 4 & 4 \\
Min & 22 & 0.24 & Min & 18 & 0.38 \\
Max & 41 & 0.51 & Max & 33 & 0.69 \\
Mean & 29.60 & 0.40 & Mean & 23.50 & 0.60 \\
Stand. dev. & 5.50 & 0.10 & Stand. dev. & 6.90 & 0.10 \\
\hline \multicolumn{7}{|l|}{ D. basiovalis: b/c ratio is doubtful in one specimen } \\
\hline \multicolumn{7}{|l}{ D. iommii } & $\mathrm{A}$ & b/c & D. viirae & $\mathrm{A}$ & $\mathrm{b} / \mathrm{c}$ \\
\hline $\mathrm{N}$ & 10 & 10 & N & 6 & 6 \\
Min & 25 & 0.41 & Min & 24 & 0.17 \\
Max & 38 & 0.75 & Max & 35 & 0.31 \\
Mean & 30.20 & 0.54 & Mean & 29.33 & 0.25 \\
Stand. dev. & 4.16 & 0.10 & Stand. dev. & 4.32 & 0.05 \\
\hline
\end{tabular}

Fig. 5. A. Results (probabilities) of the nonparametric PERMANOVA test performed on the first seven components of the PCA plot. Drepanoistodus basiovalis (Sergeeva, 1963) and the three new species, D. iommii sp. nov., D. svendi sp. nov. and D. viirae sp. nov. The three tested null hypotheses are that D. basiovalis is similar to each of the three new species, respectively. Because all the test results are below 0.05 , the three null hypotheses are rejected, and there is no statistical evidence from the test that the groups (species) are similar. B. Univariate statistics with regard to the measured angle A and the calculated $\mathrm{b} / \mathrm{c}$ ratio. Abbreviations: $\mathrm{N}=$ number of measured specimens; $\mathrm{Min}=$ lowest number; $\mathrm{Max}=$ highest number; Mean = average; Stand. dev. $=$ standard deviation. All calculations were performed using the PAST software (Hammer et al. 2001). 


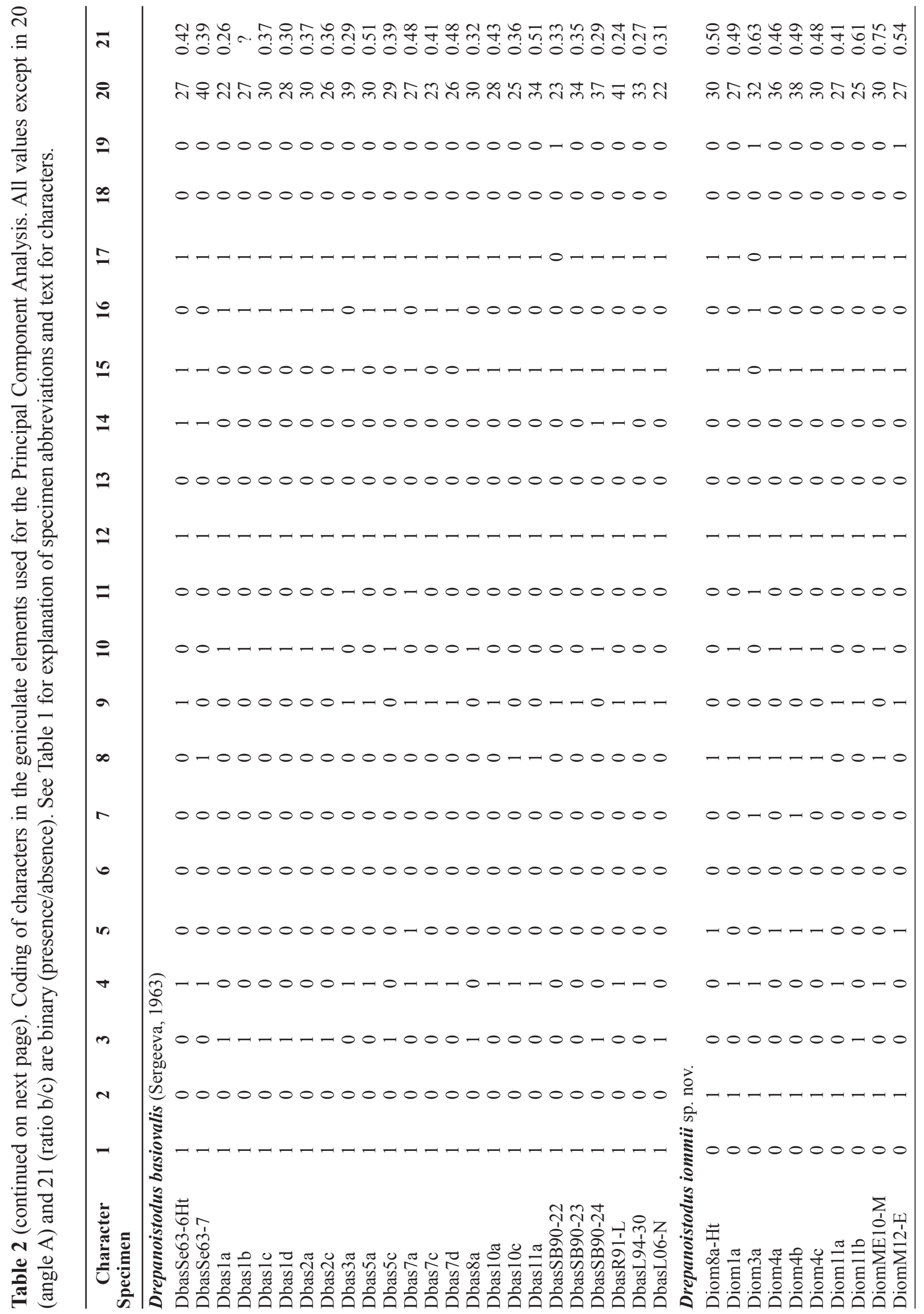




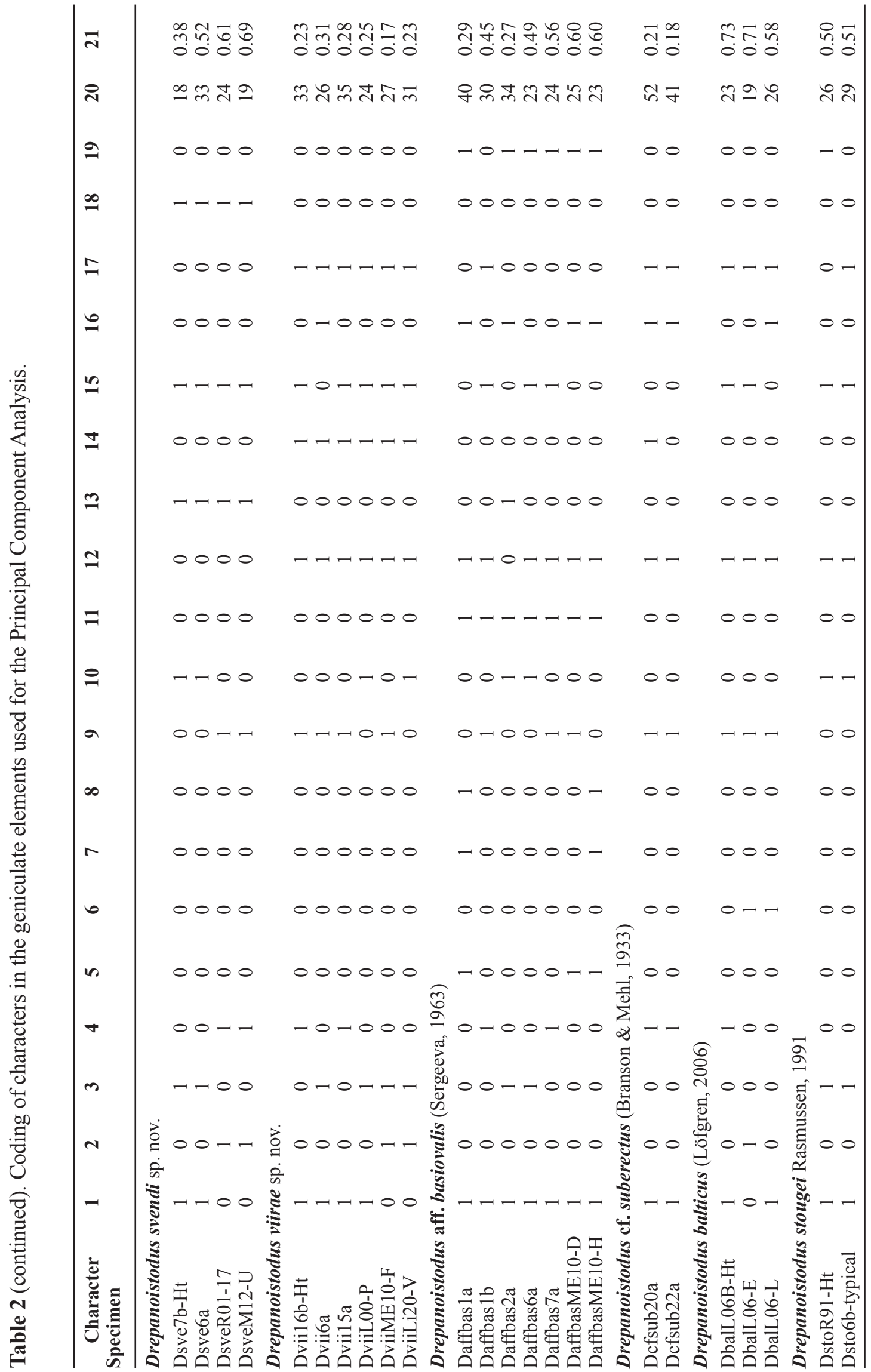




\section{Species characters and coding}

In total, the data matrix at hand comprises 21 discrete morphological characters related to the geniculate element in Drepanoistodus (Table 2; Fig. 3). Whereas 19 of these characters are binary (presence $=1$; absence $=0$ ), two are measured values, i.e., the angle between the upper margin and the cusp, and the ratio between the length of the upper margin and the cusp, respectively. If a character is missing because of damage (fragmentation), the character has been coded with a question mark (?).

1. Basal margin convex (BaMaConv): present (1), absent (0).

2. Basal margin straight (BaMaStra): present (1), absent (0).

3. Anterior margin convex (AnMaConv): present (1), absent (0).

4. Anterior margin weakly convex (AnMaWCon): present (1), absent (0).

5. Anterior margin straight (AnMarStra): present (1), absent (0).

6. Anterior margin makes a pointed extension in the middle part (AntMarPoMi): present (1), absent (0).

7. Anterior margin makes a pointed extension in the upper anterior corner (AntMarPoUp): present (1), absent (0).

8. Upper anterior corner is angular (UpAntAng): present (1), absent (0).

9. Upper anterior corner is weakly rounded (UpAntWRou): present (1), absent (0).

10. Upper anterior corner is rounded (UpAntRou): present (1), absent (0).

11. A keel-like extension is developed in the upper anterior corner (KeeExt): present (1), absent (0).

12. Cusp is straight (CuStra): present (1), absent (0).

13. Cusp is bent downward (CuDoBe): present (1), absent (0).

14. A weakly developed carina is present on the inner side of the cusp (WCarPres): present (1), absent (0).

15. A distinct longitudinal carina is developed in the median part of the cusp (CarMed): present (1), absent (0).

16. A distinct longitudinal carina is developed in the lower half part of the cusp (CarLow): present (1), absent (0).

17. Carina is straight (CarStra): present (1), absent (0).

18. Carina is bent downward anteriorly (CarBow): present (1), absent (0).

19. Carina is bent weakly downward anteriorly (CarWBow): present (1), absent (0).

20. Angle A is located between carina and lower margin of keel on upper margin: measured value A.

21. Ratio between length of upper margin (b) and length of free cusp (c) (b/c): measured ratio b/c.

Calculated means and standard deviations of the angle $A$ and the $b / c$ ratio (characters 20 and 21) for each of the new species and D. basiovalis are illustrated in Fig. 5B.

\section{Results}

\section{Systematic palaeontology}

Infraphylum Vertebrata Lamarck, 1801

Class Conodonta Eichenberg, 1930

Order Protopanderodontida Sweet, 1988

Family Drepanoistodontidae Bergström, 1981

Genus Drepanoistodus Lindström, 1971

\section{Type species}

Oistodus forceps Lindström, 1955, subsequently designated by Lindström (1971). 


\section{Remarks}

Drepanoistodus is here interpreted as quinquemembrate and comprises four nongeniculate coniform elements and one geniculate coniform element that collectively make a curvature-transition series from erect to recurved element types (e.g., Stouge \& Bagnoli 1990; Rasmussen 1991). The nongeniculate elements comprise a suberectiform element associated with drepanodontiform type-1, type-2 and type-3 elements. In general, Middle Ordovician nongeniculate Drepanoistodus elements from Baltica can be described as follows: the suberectiform element is characterised by a straight, erect cusp. The drepanodontiform type-1 element has a strongly recurved cusp, which is keeled both anteriorly and posteriorly. The anterior keel is twisted strongly inwards. An extension, sometimes triangular in outline, may occur at the anterobasal corner. The drepanodontiform type-2 element has a recurved cusp which is keeled. It is separated from the drepanodontiform type-1 element by the straight or only weakly twisted anterior margin, and by the consistent presence of an anterobasal flare, commonly with a triangular outline. The drepanodontiform type-3 element is typified by a slightly recurved cusp, which is anteriorly and posteriorly keeled and not twisted. As opposed to the drepanodontiform type- 1 and type- 2 elements, it lacks the anterior triangular flare. For a more comprehensive description, see Rasmussen (1991).

Many coniform conodont apparatuses are not easily placed in the locational PMS notation scheme favoured by Sweet $(1981,1988)$, or the more biologically correct terminology advocated by Purnell et al. (2000), because it is very difficult or even impossible to identify locational homologues with the ozarkodinid notation (Smith et al. 2005). This is primarily a consequence of the lack of natural assemblages in many conodont genera and families, including Drepanoistodus.

In most cases, it is extremely difficult to distinguish between individual Middle Ordovician Drepanoistodus species based on the largely homeomorphic nongeniculate elements (van Wamel 1974; Dzik 1983; Stouge 1984; Rasmussen 2001), and this is indeed also the case with respect to the species studied herein. Because our material includes nothing but isolated conodont elements (as opposed to articulated clusters or natural multi-element assemblages), the identification of Drepanoistodus at the species level is solely based on the geniculate element, which are described below. The stratigraphical distribution of the studied specimens of Drepanoistodus is shown in Table 3.

Drepanoistodus basiovalis (Sergeeva, 1963)

Fig. 6A-D

Oistodus basiovalis Sergeeva, 1963: 96, pl. 7 figs 6-7, text-fig. 3.

Drepanoistodus basiovalis - Lindström 1971: 43, text-figs 6, 8. — Stouge \& Bagnoli 1990: 15, pl. 5 figs 18-24. — Dzik 1990: fig. 12; 1994: 78, pl. 16 figs. 16-20, text-fig. 12a; 2020: fig. 7A-E. Rasmussen 1991: 277, fig. 61; 2001: 71-73, pl. 5: 9 (cum. syn.). — Löfgren 1994: fig. 6.30; 2000a: fig. 4w; 2006: figs 3n, 3ab. — Viira et al. 2001: fig. 5z. — Zhen \& Percival 2004: 93, fig. 11a-j. — Tolmacheva et al. 2013: pl. 3, fig. 24.

partim Drepanoistodus basiovalis - Löfgren 1978: 55-56, pl. 1 figs 11-16 (only), non 17 (=D. contractus (Lindström, 1955)). — Olgun 1987: 49, pl. 6w (only). — Landing et al. 2003: fig. 4e (only). — Zhen et al. 2011: 222-227, fig. 12a?, b-n, p-q (only).

cf. Drepanoistodus basiovalis - Zhang 1998: 61-62, pl. 5 figs 5-12 (unusually short upper margin of the base).

? Drepanoistodus basiovalis - Lehnert et al. 1998: 55, pl. 3 figs 6, 12 (12 may belong to Paroistodus originalis (Sergeeva, 1963)). — Boncheva et al. 2009: text-fig. 3.8 (broken element). — Albanesi \& Ortega 2016: fig. 7(6) (shares characters with D. basiovalis and D. cf. balticus). - Feltes et al. 2016: fig. 3ac. - Wu et al. 2018: fig. 5e (unusually long base compared to the cusp). 
non Drepanoistodus basiovalis - Gutiérrez-Marco et al. 2008: 153, figs 3.29-3.31 (may be Drepanoistodus cf. basiovalis or Drepanoistodus cf. suberectus (Branson \& Mehl, 1933). - Hints et al. 2012: fig. 6h (= Drepanoistodus cf. suberectus). - Wu et al. 2017: fig. $7 \mathrm{u}$ (= Drepanoistodus contractus (Lindström)). — Lindskog et al. 2020: fig. 7v-w (= Drepanoistodus viirae sp. nov.).

Original diagnosis (translated from Sergeeva, 1963 [in Russian])

Inclined conodonts, almost symmetrical, with a wide shortened base, the edge of which is rounded.

\section{Material examined}

33 geniculate elements including 24 from the Lynna section.

Original description, slightly shortened (translated from Sergeeva, 1963 [in Russian])

Medium-sized conodonts $(0.52-0.92 \mathrm{~mm})$, inclined; the degree of inclination of the cusp is $45-60^{\circ}$, sometimes up to $80^{\circ}$. Base high, not very long, elongated along the $\mathrm{CD}$; base length 2.5-3 times its height (comment by the authors: "we find the meaning of the latter measure ambiguous"). Base wall slightly transparent near the edge, rounded. The angle between the sides AC is more than $90^{\circ}$; angle between AD 40-45 ; corners are smoothly obtuse. Transverse in cross section, the base is oval, elongated along CD and compressed along L1L2. From the $\mathrm{C}$ side, the base is compressed, sometimes with a thin keel near the tip, with a small keel on side D. The sides of the base L1 and L2 are smooth and flat. Basal cavity is not always visible, it is wide, but not deep, without visible tops. The cusp is long, straight or slightly curved towards L1, sharply tapering towards the tip; compressed. The sides of the cusp are almost flat, with a welldeveloped longitudinal, wide carina on L1 and less developed carina on the side L2. The carinae usually run from the base to the tip of the cusp. Thin keels occur on the lower (D) and upper (C) parts of the cusp.

\section{Remarks}

In her original diagnosis, Sergeeva (1963) only included geniculate elements with a rounded basal margin in "Oistodus" basiovalis, which is also evident from the species epithet: basiovalis (meaning oval base). This interpretation of the geniculate element in Drepanoistodus basiovalis is followed here. Additional typical characters that may be added to the original species description include: anterior margin and upper anterior corner rounded or weakly rounded; cusp usually straight; a median or median to lower, longitudinal carina present on the inner (sometimes slightly concave) side of the element. Carina is more distinct in Darriwilian specimens than in Dapingian ones. Whereas angle A (Fig. 3) between the cusp and the upper margin is $29.6^{\circ}$ with a standard deviation at 5.6, the mean ratio between the length of the free upper margin and free cusp (b/c ratio) reaches 0.40 with a standard deviation of 0.1 (Fig. 5B).

\section{Occurrence}

Drepanoistodus basiovalis occurs from the L. antivariabilis Zone (sample LY12-9) to the interzone ("uncertain interval") between the L. variabilis Zone and the $Y$. crassus Zone sensu Lindskog et al. (2020) in the Lynna River section (sample LY12-21b; between LY12-21 and LY12-22). In addition, D. basiovalis has been reported from several other localities in Baltoscandia and Poland, and also outside the Baltica palaeocontinent, e.g., New Brunswick, Argentina, Australia and China (for references, see the synonymy list above).

Drepanoistodus iommii sp. nov.

urn:1sid:zoobank.org:act:0E2832F5-672E-4FAE-B5A5-CBA5DE1A4824

Fig. 6E-H

partim Drepanoistodus aff. basiovalis - Mellgren \& Eriksson 2010: fig. 7m (only).

Drepanoistodus cf. basiovalis - Mellgren et al. 2012: fig. 5e. 


\section{Diagnosis}

A Drepanoistodus species characterised by a geniculate element with distinct keels on the cusp and upper margin of the base; a straight basal margin; a straight to weakly rounded (convex) anterior margin and cusp which is approximately twice the length of the upper margin of the base.

\section{Etymology}

Named in honour of legendary guitarist Tony Iommi, founding member of heavy metal band Black Sabbath.

\section{Material examined}

Ten geniculate elements including eight from the Lynna section.

Holotype, geniculate element (Fig. 6E-F); LO 12479T.

\section{Type locality}

River bank near the mouth of Lynna River, village of Kolchanovo, St. Petersburg region, Russia $\left(60^{\circ} 00^{\prime} 39^{\prime \prime} \mathrm{N}, 32^{\circ} 33^{\prime} 49^{\prime \prime} \mathrm{E}\right)$.

\section{Type stratum}

Approximately $10 \mathrm{~cm}$ above the local base of the Lynna Formation, sample LY12-16. Lower part of the Lenodus variabilis Zone.

\section{Description}

Cusp reclined and straight with distinct keels developed on the anterior (upper) and posterior (lower) margins. A median, longitudinal carina is developed on both sides of the cusp, but it is especially distinct on the inner side. Base is characterised by a straight or almost straight basal margin and a distinct keel on the upper margin. Whereas this keel is slightly convex, the upper margin below the keel is straight. Anterior margin is usually straight or weakly rounded (convex), but occasionally, it is strongly rounded. Angle A between the cusp and upper margin of the base is ca $30^{\circ}$ (mean) with a standard deviation at 4.2 (Fig. 5B), and the mean ratio between length of the free upper margin (b) and the free cusp (c) is 0.54 (standard deviation 0.10).

\section{Remarks}

In the PCA plot (Fig. 4), the population of D. iommii sp. nov. is situated in the upper right corner, separated from the D. basiovalis population as well as the other two new species populations described herein. The vectors in the biplot demonstrate that this is mainly due to the straight basal margin, the relatively long upper margin (high $\mathrm{b} / \mathrm{c}$ values), and the usually straight anterior margin in $D$. iommii sp. nov., which is in accordance with the characters diagnosed above. The hypothesis that the population of $D$. iommii sp. nov. is morphologically different from the $D$. basiovalis population is supported by the PERMANOVA test (Fig. 5A), which shows that the probability that the two populations are the same is exceedingly low $(\mathrm{p}(\mathrm{same})=1.00 \mathrm{E}-04)$.

\section{Occurrence}

The L. antivariabilis Zone (sample LY12-9) to the L. variabilis Zone (sample LY12-21b). Outside the St. Petersburg region, $D$. iommii sp. nov. has been recorded from the L. variabilis Zone at the Hällekis quarry in Västergötland, Sweden (Mellgren \& Eriksson 2010; referred to as D. aff. basiovalis) and from the L. pseudoplanus Zone or E. suecicus Zone of the island Osmussaar, Estonia (Mellgren et al. 2012; reported as $D$. cf. basiovalis). 


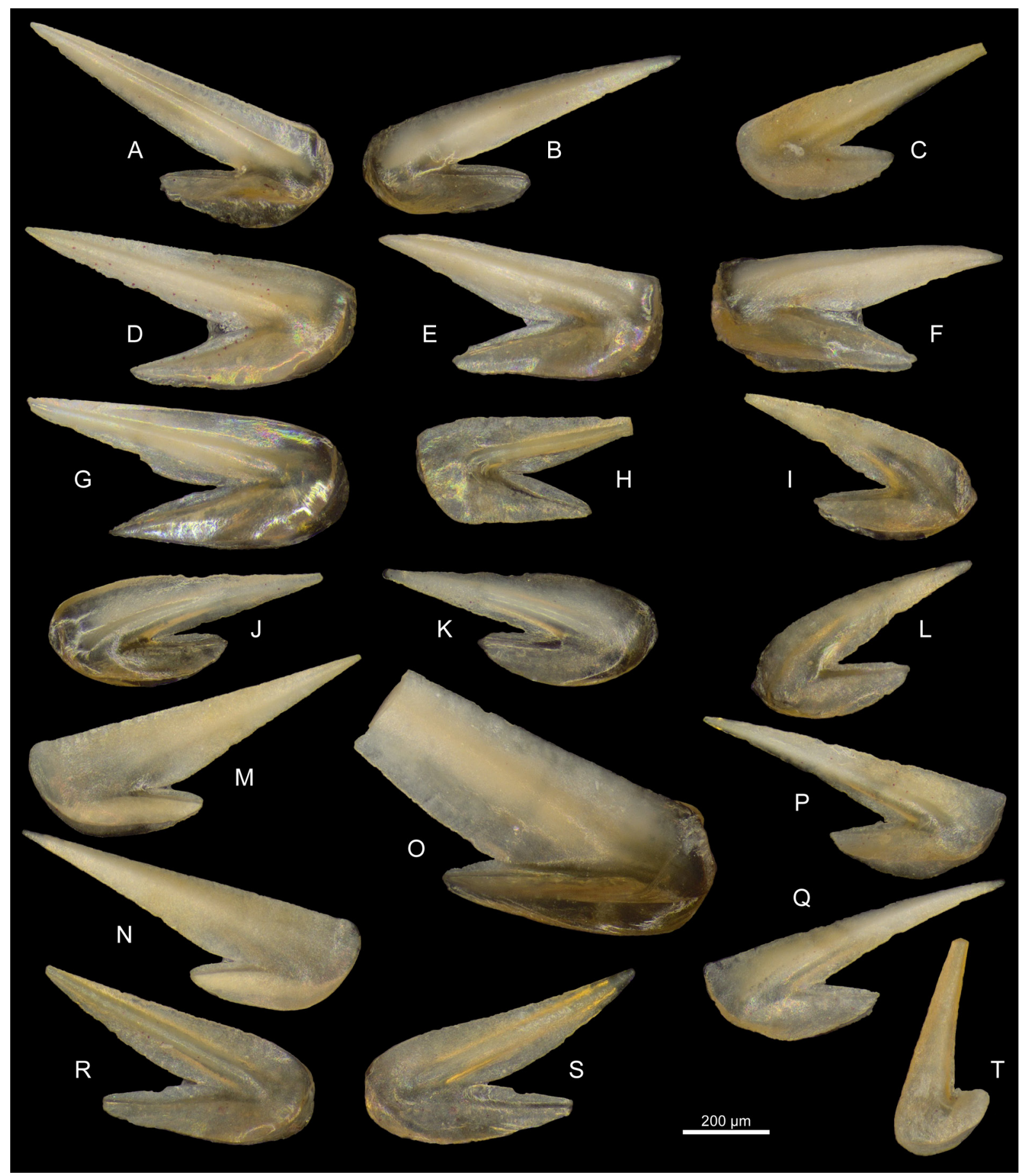

Fig. 6. Light microscopy photographs of selected geniculate elements of species of Drepanoistodus, as outlined herein, from the Lynna River section, Russia. A-D. Drepanoistodus basiovalis (Sergeeva, 1963). A. LO 12476t, inner view, sample LY12-16, L. variabilis Zone. B. Same specimen as A in outer view. C. LO 12477t, inner view, sample LY12-9, L. antivariabilis Zone. D. LO 12478t, inner view, sample LY12-21b, L. variabilis Zone. E-H. Drepanoistodus iommii sp. nov. E. LO 12479T, holotype, inner view, sample LY12-16, L. variabilis Zone. F. Same specimen as E in outer view. G. LO 12480t, inner view, sample LY12-21b, L. variabilis Zone. H. LO 12481t, inner view, sample LY12-3, L. antivariabilis Zone. I-L. Drepanoistodus svendi sp. nov. I. LO 12482t, inner view, sample LY12-13, L. variabilis Zone. J-K. LO 12483T, holotype, inner and outer view, respectively, sample LY12-14, L. variabilis 


\section{Drepanoistodus svendi sp. nov. \\ urn:1sid:zoobank.org:act:0921F27A-ECF6-498C-8943-4DEB96CFBB38}

Fig. 6I-L

Drepanoistodus aff. basiovalis (Sergeeva) - Rasmussen 2001: 73-74, pl. 5 fig. 17.- Mellgren et al. 2012: fig. $5 u$.

\section{Diagnosis}

A Drepanoistodus species characterised by a geniculate element with a recurved cusp and distinct keels on both the cusp and the upper margin of the base. Weakly curved but distinct carinas are developed on both sides of the cusp, especially well developed on the inner side.

\section{Etymology}

Named after the Danish palaeontologist and conodont specialist Svend S. Stouge, Natural History Museum of Denmark, University of Copenhagen.

\section{Material examined}

Five geniculate elements including three from the Lynna section.

Holotype, geniculate element (Fig. 6J-K); LO 12483T.

\section{Type locality}

River bank near the mouth of Lynna River, village of Kolchanovo, St. Petersburg region, Russia $\left(60^{\circ} 00^{\prime} 39^{\prime \prime} \mathrm{N}, 32^{\circ} 33^{\prime} 49^{\prime \prime} \mathrm{E}\right)$.

\section{Type stratum}

Approximately $40 \mathrm{~cm}$ below the local top of the Volkhov Formation, sample LY12-14, ca $20 \mathrm{~cm}$ above the base of the Lenodus variabilis Zone sensu Lindskog et al. (2020).

\section{Description}

Cusp is recurved (bent weakly downward), with distinct keels developed along the anterior (upper) and posterior (lower) margins. A median, longitudinal, weakly curved carina is developed on both sides of the cusp, most distinct on the inner side of the cusp. Cusp is almost twice as long as the upper margin of the cusp; the mean ratio between the length of the free upper margin and the free cusp (Fig. 3) is ca 0.55 with a standard deviation of 0.13 . Basal margin varies from rounded (convex) to almost straight. A distinct keel is developed on the upper margin. Anterior margin is rounded or weakly rounded (convex). Angle A (Fig. 3) between the cusp and upper margin of the base varies considerable with a mean of $24^{\circ}$ and standard deviation of 6.9 (Fig. 5B).

Zone. L. Same specimen as I in outer view. M-O. Drepanoistodus viirae sp. nov. M. LO 12484T, holotype, inner view, sample LY12-31, interzone ("uncertain interval") between the Lenodus variabilis Zone and the Yangtzeplacognathus crassus Zone sensu Lindskog et al. (2020). N. Same specimen as M in outer view. O. LO 12485t, inner view, sample LY 12-31, interzone ("uncertain interval") between the Lenodus variabilis Zone and the Yangtzeplacognathus crassus Zone sensu Lindskog et al. (2020). P-Q. Drepanoistodus aff. basiovalis (Sergeeva, 1963), LO 12486t, inner and outer view, respectively, sample LY12-9, L. antivariabilis Zone. R-S. Drepanoistodus stougei Rasmussen, 1991, LO 12487t, inner and outer view, respectively, sample LY12-13, L. variabilis Zone. T. Drepanoistodus cf. suberectus (Branson \& Mehl, 1933), LO 12488t, inner view, sample LY14-2, Y. crassus Zone. Scale bar $=200 \mu \mathrm{m}$ (all specimens illustrated at same scale). 


\section{Remarks}

Drepanoistodus svendi sp. nov. is distinguished from all the other Drepanoistodus species in the present study by the recurved cusp and the curved carina on each side of the cusp. Like $D$. iommii sp. nov., it is characterised by a clearly longer upper margin of the base compared to the cusp length than in $D$. basiovalis. The $D$. svendi sp. nov. population is located in the lower, right quadrangle of the PCA plot, far from any other species of Drepanoistodus, and the biplot vectors representing the recurved cusp and the curved carina point in this direction (Fig. 4). The PERMANOVA test on the first seven PCA axis shows that the probability that the D. basiovalis and D. svendi sp. nov. populations are the same, is exceedingly low $(\mathrm{p}$ (same) $=1.00 \mathrm{E}-04)$.

\section{Occurrence}

The lower part of the L. variabilis Zone (samples LY12-13, LY12-14). Moreover, D. svendi sp. nov. has been recorded from Steinsodden, Norway, from the top of the B. norrlandicus - D. stougei Zone and the base of the overlying B. medius $-H$. holodentata Zone, which correlate with the middle part of the L. variabilis Zone (as D. aff. basiovalis sensu Rasmussen 2001), and from the L. pseudoplanus Zone or E. suecicus Zone at the island Osmussaar, Estonia (Mellgren et al. 2012; reported as D. aff. basiovalis).

\section{Drepanoistodus viirae sp. nov. urn:Isid:zoobank.org:act:AD10D9B3-9802-4DAC-97C0-B44EB8DE195D}

Fig. $6 \mathrm{M}-\mathrm{O}$

Drepanoistodus basiovalis (Sergeeva, 1963) - Löfgren 2000b: fig. 4p; 2003: fig. 7aa. — Lindskog et al. 2020: fig. $7 \mathrm{v}-\mathrm{w}$.

partim Drepanoistodus cf. basiovalis - Rasmussen 2001: 73, pl. 5 fig. 16 (only).

Drepanoistodus cf. stougei Rasmussen, 1991 - Rasmussen 2001: 76, pl. 6 fig. 12.

Drepanoistodus aff. suberectus (Branson \& Mehl, 1933) - Mellgren \& Eriksson 2010: fig. 7f.

aff. Drepanoistodus basiovalis - Feltes \& Albanesi 2013: fig. 3.12.

? partim Drepanoistodus basiovalis - Zhen 2020: 18-19, fig. 7b (only).

\section{Diagnosis}

A Drepanoistodus species characterised by a geniculate element with a wide, straight, compressed cusp and a very short base, where the free cusp typically is ca 4 times longer than the upper margin of the base.

\section{Etymology}

Named after the Estonian palaeontologist and conodont specialist Viive Viira, Tallinn University of Technology, Estonia.

\section{Material examined}

Nine geniculate elements including five from the Lynna section.

Holotype, geniculate element (Fig. 6M-N); LO $12484 \mathrm{~T}$.

\section{Type locality}

River bank near the mouth of Lynna River, village of Kolchanovo, St. Petersburg region, Russia $\left(60^{\circ} 00^{\prime} 39^{\prime \prime} \mathrm{N}, 32^{\circ} 33^{\prime} 49^{\prime \prime} \mathrm{E}\right)$. 


\section{Type stratum}

Approximately $15 \mathrm{~cm}$ above the local base of the Sillaoru Formation, sample LY12-31. Lower part of the $90 \mathrm{~cm}$ thick interzone ("uncertain interval") between the Lenodus variabilis Zone and the Yangtzeplacognathus crassus Zone sensu Lindskog et al. (2020).

\section{Description}

Cusp is reclined, wide (from upper to lower margin) and straight, with keels developed along the anterior (upper) and posterior (lower) margins. A weak, median, longitudinal carina is developed on the inner side of the cusp. Occasionally, the carina may be distinct. Basal margin is weakly rounded or straight. A distinct keel is developed on the upper margin. Anterior margin is rounded or weakly rounded (convex). Angle A (Fig. 3) between the cusp and upper margin of the base is ca $30^{\circ}$ (mean) with a standard deviation of 4.3 (Fig. 5B), and mean ratio between length of the free upper margin and the free cusp is ca 0.25 with a standard deviation of 0.05 .

\section{Remarks}

Drepanoistodus viirae sp. nov. is situated in the lower left quadrangle of the PCA plot (Fig. 4). Like $D$. basiovalis, it is clearly separated from $D$. iommii sp. nov. and $D$. svendi sp. nov., whereas it partly overlaps with the D. basiovalis population, when only the PC 1 (x) and PC 2 (y) axis is plotted. The vectors in the biplot reinforce that $D$. viirae sp. nov. is characterised by a convex basal margin, a weakly developed carina and a short upper margin on the base ( $=$ low b/c value), the latter because it is situated in the opposite direction of the b/c vector, as seen in Fig. 4. The partial overlap with D. basiovalis occurs because the two species share some characters. A significant difference, however, is that $D$. viirae sp. nov. has a relatively shorter upper margin of the base, where the mean $\mathrm{b} / \mathrm{c}$ ratio is $0.40 \mathrm{in} D$. basiovalis but only 0.25 in $D$. viirae sp. nov. (Fig. 5B). Moreover, D. viirae sp. nov. is characterised by a wider cusp when viewed from the side and, typically, a less developed carina on the cusp. The hypothesis that the $D$. viirae sp. nov. population is morphologically separate from the $D$. basiovalis population is supported by the PERMANOVA test (Fig. 5A), which shows that the probability that the two populations are the same is low $(\mathrm{p}$ (same $)=8.00 \mathrm{E}-03)$. Drepanoistodus viirae sp. nov. is distinguished from the stratigraphically older Drepanoistodus contractus on the relatively wider and more compressed cusp and the usually less distinct longitudinal carina, and from $D$. cf. suberectus on the markedly smaller angle between the cusp and the upper margin of the base (mean angle $=46^{\circ}$ in $D$. cf. suberectus, $30^{\circ}$ in $D$. viirae sp. nov.).

\section{Occurrence}

The lower part of the L. variabilis Zone (sample LY12-13) to the lower part of the interzone ("uncertain interval") between the $L$. variabilis Zone and the Y. crassus Zone (sample LY12-31) sensu Lindskog et al. (2020). In addition, D. viirae sp. nov. has been recorded from the B. norrlandicus and basal $Y$. crassus zones at Gillberga, Sweden (Löfgren 2000b, 2003); the uppermost part of the P. rectus - M. parva Zone at Steinsodden, Norway, which correlates with the uppermost $P$. originalis Zone (as $D$. cf. stougei sensu Rasmussen 2001); the lower part of the B. medius - H. holodentata Zone at Andersön, Sweden, correlating with the uppermost part of the L. variabilis Zone (as D. cf. basiovalis sensu Rasmussen 2001), and the L. variabilis Zone at Hällekis, Sweden (as D. aff. suberectus sensu Mellgren \& Eriksson 2010). Moreover, it shares some characteristics with the geniculate element from strata correlated with the L. pseudoplanus Zone of the Canning Basin, Australia, which was included in D. basiovalis (Zhen 2020: fig. 7b), but this identification is questionable.

\section{Taxonomical notes}

Drepanoistodus aff. basiovalis (Sergeeva, 1963)

Fig. 6P-Q

aff. Oistodus basiovalis Sergeeva, 1963: 96, pl. 7 figs. 6-7, text-fig. 3. 


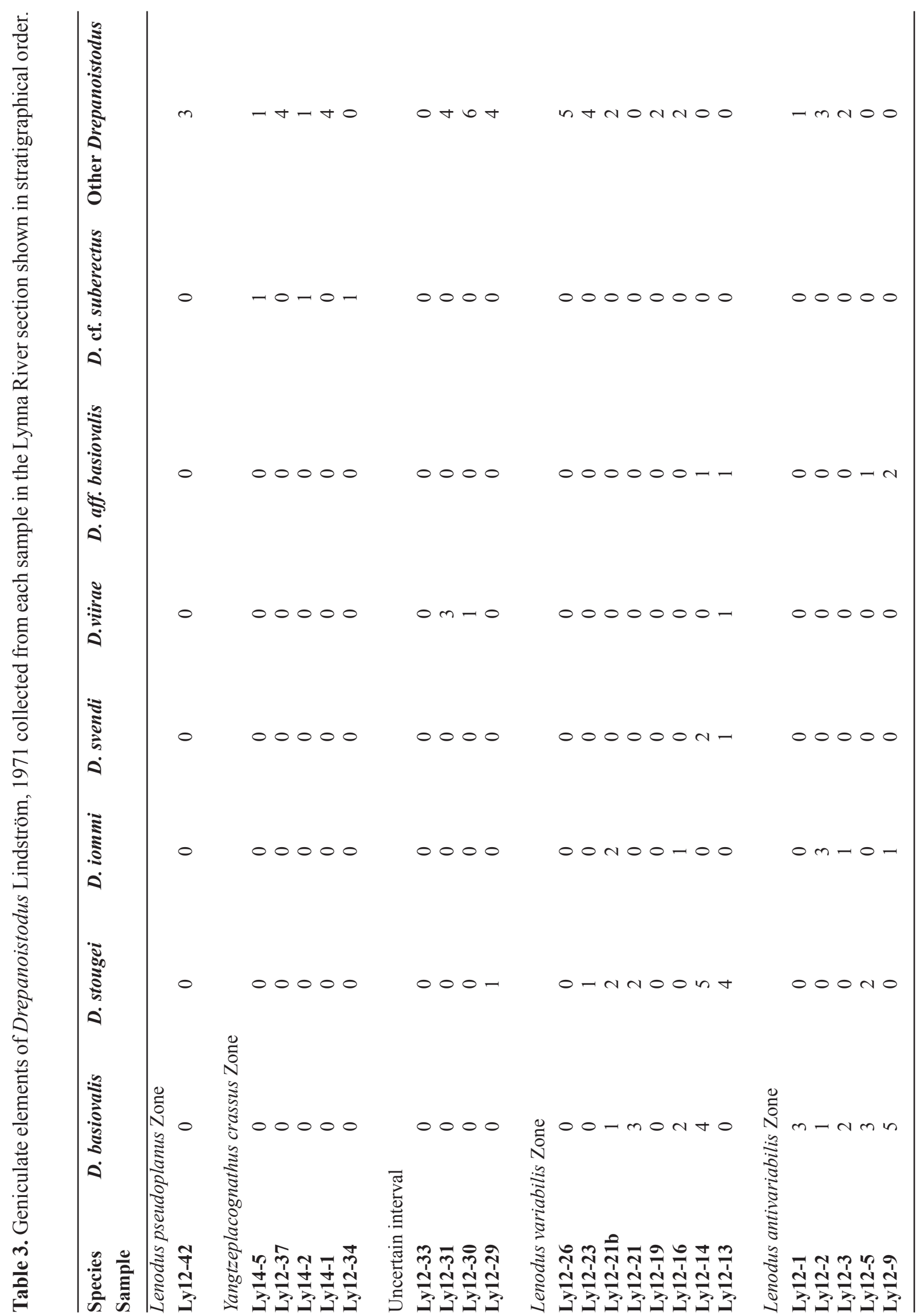


Drepanoistodus cf. basiovalis (Sergeeva, 1963) - Löfgren 2000a: fig. 4v.

Drepanoistodus aff. basiovalis - Mellgren \& Eriksson 2010: fig. 7g-h.

Drepanoistodus basiovalis - Serra et al. 2019: fig. 7k. - Wu et al. 2020: fig. 3ah-ai.

\section{Material examined}

Seven geniculate elements including five from the Lynna section.

\section{Remarks}

The specimens assigned to Drepanoistodus aff. basiovalis herein share some characters with D. basiovalis, D. iommii sp. nov. and D. stougei, but do not meet the full criteria of any of these species. The most significant character is an extended upper keel anteriorly, which may be angular (see Fig. 6P-Q) or rounded. Cusp is reclined and straight with distinct carinas on both sides of the cusp. Anterior margin varies from almost straight to rounded (convex). The upper anterior corner is angular or weakly rounded. The basal margin is usually slightly convex. The cusp is often nearly twice as long as the upper margin of the base, but it varies considerably ( $\mathrm{b} / \mathrm{c}$ ratio mean $=0.46$, standard deviation 0.14 ). Similarly, angle $\mathrm{A}$ is very variable with a mean near $28^{\circ}$ and standard deviation at 6.55 (Fig. 5B). Specimens with a rounded anterior edge share similarity with Drepanoistodus stougei Rasmussen, 1991 but are distinguished by the extended upper keel anteriorly, and a more narrow and distinct carina. More material and analyses are needed to assess if this taxon represents a separate species. Thus, for the time being, these specimens are left under open nomenclature.

\section{Occurrence}

The L. antivariabilis Zone (sample LY12-9) to the basal part of the L. variabilis Zone (sample LY1214). Moreover, it has been recorded from the B. norrlandicus Zone at Gillberga, Sweden (Löfgren 2000a, as D. cf. basiovalis); the L. variabilis Zone at Hällekis, Sweden (Mellgren \& Eriksson 2010); and also from the L. pseudoplanus Zone of the Argentine Precordillera (Serra et al. 2019, as D. basiovalis) and Histiodella kristinae Zone of Zhejiang, China (Wu et al. 2020, as D. basiovalis).

Drepanoistodus stougei Rasmussen, 1991

Fig. 6R-S

\section{Material examined}

22 geniculate elements including 17 from the Lynna section.

\section{Remarks}

Drepanoistodus stougei was first described by Rasmussen (1991) and further morphological details for all the four element types were subsequently added by Rasmussen (2001). The most distinct features are the rounded anterior margin and the relatively long upper margin on the base. In the material at hand, the b/c ratio (see Fig. 3) mean is 0.50 and angle A has a mean of $27.4^{\circ}$. In some cases, $D$. svendi sp. nov. is characterized by a similarly rounded anterior margin but is distinguished by its (weakly) curved cusp and carina. Drepanoistodus aff. basiovalis morphotypes with a rounded anterior margin are separated from $D$. stougei by the characteristically extended keel in the upper anterior corner of the former taxon. Because $D$. stougei is included here just for comparison with the new species described, synonymy or further descriptive details have not been incorporated, but can be found in Rasmussen $(1991,2001)$.

\section{Occurrence}

From the Lenodus antivariabilis Zone (sample LY12-5) to the basal part of the interzone ("uncertain interval"; sample LY12-29) between the L. variabilis Zone and the Y. crassus Zone sensu Lindskog et al. (2020) in the Lynna River section. 
Drepanoistodus cf. suberectus (Branson \& Mehl, 1933)

Fig. 6T

Drepanoistodus cf. suberectus (Branson \& Mehl, 1933) - Löfgren 2003: fig. 7s-u. - Mellgren \& Eriksson 2010: fig. 7k (only). - Hints et al. 2012: fig. 6h.

\section{Material examined}

Four geniculate elements including three from the Lynna section.

\section{Remarks}

Drepanoistodus cf. suberectus is included in the present work because it superficially resembles Drepanoistodus viirae sp. nov. Originally, D. suberectus was described as Oistodus suberectus from the Upper Ordovician strata of Missouri, USA, by Branson \& Mehl (1933), but it was not until 1966 that conodont specialists included the geniculate element in the apparatus (see Bergström \& Sweet 1966 and Webers 1966, for details). The D. suberectus type locality near Ozora, Missouri, was located and restudied by Bergström \& Leslie (2010) who documented the conodont fauna and illustrated three different elements of $D$. suberectus, including the geniculate element. The Upper Ordovician geniculate D. suberectus elements (e.g., Stauffer 1935; Nowlan 2002; Bergström \& Leslie 2010) are generally more rounded anteriorly and carry more pronounced keels on the cusp than the three geniculate elements at hand, thus leading us to leave the Lynna River specimens in open nomenclature.

Drepanoistodus cf. suberectus occurs only sporadically in the Lynna River section samples. It is characterised by a short upper margin of the base compared to the free cusp (b/c ratio near 0.20 in the three specimens found). Angle A between the upper margin of the cusp and the carina on the cusp (see Fig. 3) varies considerably $\left(41-52^{\circ}\right)$ but it is wider than that of the other Drepanoistodus species described here. Moreover, it is typified by a convex basal margin; weakly rounded anterior margin, and a weakly developed carina on the straight cusp, which is located on the lower half part of the cusp.

Superficially, $D$. cf. suberectus resembles $D$. viirae sp. nov. because of the relatively short base, but the latter species is distinguished by a narrower angle A (see Fig. 3); wider sides anteriorly on the cusp; laterally compressed cusp with distinct keels, and a median, as opposed to a lower, carina.

\section{Occurrence}

The Yangtzeplacognathus crassus Zone at Lynna River (samples LY12-34, LY14-2 and LY14-5). Drepanoistodus cf. suberectus has also been documented from the L. variabilis Zone of Hällekis, Sweden (Mellgren \& Eriksson 2010).

\section{Discussion}

The present study not only assesses the debated Ordovician conodont genus, Drepanoistodus, but also adds to our general knowledge of this useful microfossil group from the St. Petersburg region - an area with an extensive historical research tradition. Herein, we show that morphotypes formerly interpreted as Drepanoistodus basiovalis include at least five separate species. Whereas two of these species were previously known as $D$. basiovalis and $D$. contractus, three are newly established herein; $D$. iommii sp. nov., $D$. svendi sp. nov. and $D$. viirae sp. nov. Notably, the establishment of $D$. iommii sp. nov. means that a conodont species is now rightfully inducted into the "rock fossil hall of fame", and that D. iommii sp. nov. will become part of the Rock Fossils travelling exhibition (see Eriksson 2019). As such, it will also benefit palaeontological outreach. 
Drepanoistodus basiovalis appears to have been stratigraphically (Fig. 2) and geographically more widespread than the four other Drepanoistodus species studied. Whereas the three new species seem to have been restricted to Baltica, D. basiovalis probably also inhabited other palaeocontinents in low numbers. Note, however, that we consider many of the records from outside Baltica (see the D. basiovalis synonymy above) to be questionable. In the Lynna River section, $D$. svendi sp. nov. is restricted to the lowermost part of the $L$. variabilis Zone, while $D$. viirae sp. nov. ranges through most of the $L$. variabilis Zone to a level just above the top of the L. variabilis Zone (Fig. 2). Drepanoistodus iommii sp. nov. appears earlier than $D$. svendi sp. nov. and $D$. viirae sp. nov. in the Lynna River Section (in the L. antivariabilis Zone) and this seems also to be the case in a regional scale, where the species has been recorded already from $P$. originalis Zone. More material is needed to assess if these range differences could be related to the cooling event and associated shallowing recorded in the lower Kundan (Rasmussen et al. 2016; Rasmussen \& Stouge 2018), or it results from other causes.

\section{Acknowledgments}

This study was funded by the Swedish Research Council (M.E.E.), the Birgit and Hellmuth Hertz' Foundation and the Royal Physiographic Society in Lund (A.L.). Git Klintvik-Ahlberg and Carsten Tell are thanked for processing of conodont samples, and Johan Lindgren is thanked for photography assistance. We are grateful to Øyvind Hammer for discussions on statistical methods. We do warmly thank M. Paul Smith and an anonymous reviewer for constructive reviews, which improved the manuscript considerably.

\section{References}

Albanesi G.L. \& Ortega G. 2016. Conodont and graptolite biostratigraphy of the Ordovician System of Argentina. In: Montenari M. (ed.) Stratigraphy and Timescales 1: 61-121. https://doi.org/10.1016/bs.sats.2016.10.002

Aldridge R.J., Briggs D.E.G., Smith M.P., Clarkson E.N.K. \& Clark N.D.L. 1993. The anatomy of conodonts. Philosophical Transactions of the Royal Society of London B 340: 405-421. https://doi.org/10.1098/rstb.1993.0082

Bauert H., Hints O., Meidla T. \& Männik P. (eds) 2014. $4^{\text {th }}$ Annual Meeting of IGCP 591, Estonia, 10-19 June 2014. Abstracts and Field Guide: 1-202. University of Tartu, Tartu.

Bergström S.M. 1988. On Pander's Ordovician conodonts: distribution and significance of the Prioniodus elegans fauna in Baltoscandia. Senckenbergiana Lethaea 69: 217-251.

Bergström S.M. \& Leslie S.A. 2010. The Ordovician zone index conodont Amorphognathus ordovicicus Branson \& Mehl, 1933 from its type locality and the evolution of the genus Amorphognathus Branson \& Mehl, 1933. Journal of Paleontology 29: 73-80. https://doi.org/10.1144/jm.29.1.73

Bergström S.M. \& Sweet W.C. 1966. Conodonts from the Lexington Limestone (Middle Ordovician) of Kentucky and its lateral equivalents in Ohio and Indiana. Bulletin of American Paleontology 50: $269-441$.

Bergström S.M., Chen X., Guitiérrez-Marco J.C. \& Dronov A. 2009. The new chronostratigraphic classification of the Ordovician System and its relations to major regional series and stages and to $\delta^{13} \mathrm{C}$ chemostratigraphy. Lethaia 42: 97-107. https://doi.org/10.1111/j.1502-3931.2008.00136.x

Boncheva I., Göncüoğlu M.C., Leslie S.A., Lakova I., Sachanski V., Saydam G., Gedik I. \& Koenigshof P. 2009. New conodont and palynological data from the Lower Palaeozoic in Northern Çamdağ, NW Anatolia, Turkey. Acta Geologica Polonica 59: 157-171. 
Branson E.B. \& Mehl M.G. 1933. Conodont studies no. 2; conodonts from Joachim (Middle Ordovician) of Missouri; from the Plattin (Middle Ordovician) of Missouri; from the Maquoketa-Thebes (Upper Ordovician) of Missouri; a study of Hinde's types of conodonts preserved in the British Museum. Missouri University Studies 8: 77-167.

Cocks L.R.M. \& Torsvik T.H. 2006. European geography in a global context from the Vendian to the end of the Palaeozoic. In: Gee D.G. \& Stephenson R.A. (eds) European Lithosphere Dynamics: 83-95. Geological Society, London. https://doi.org/10.1144/GSL.MEM.2006.032.01.05

Davis J.C. 1986. Statistics and Data Analysis in Geology. John Wiley \& Sons, New York.

Donoghue P.C.J., Forey P.L. \& Aldridge R.J. 2000. Conodont affinity and chordate phylogeny. Biological Reviews 75: 191-251. https://doi.org/10.1111/j.1469-185X.1999.tb00045.x

Dronov A. \& Mikuláš R. 2010. Paleozoic Ichnology of St. Petersburg Region: Excursion Guidebook. Geological Institute, Russian Academy of Sciences, Moscow.

Dzik J. 1983. Early Ordovician conodonts from the Barrandian and Bohemian-Baltic faunal relationships. Acta Palaeontologica Polonica 28: 327-368.

Dzik J. 1990. Conodont evolution in high latitudes of the Ordovician. Courier Forschungsinstitut Senckenberg 117: 1-28.

Dzik J. 1994. Conodonts of the Mojcza Limestone. In: Dzik D., Olempska E. \& Pisera A. (eds) Ordovician Carbonate Platform Ecosystem of the Holy Cross Mountains. Palaeontologica Polonica 53: 43-128.

Dzik J. 2020. Ordovician conodonts and the Tornquist Lineament. Palaeogeography, Palaeoclimatology, Palaeoecology 549: 1-20. https://doi.org/10.1016/j.palaeo.2019.04.013

Epstein A.G., Epstein J.B. \& Harris L.D. 1977. Conodont color alteration - an index to organic metamorphism. Geological Survey Professional Paper 995: 1-27. https://doi.org/10.3133/pp995

Eriksson M.E. 2019. Another Primordial Day - The Paleo Metal Diaries. PMET Publishing House, Malmö.

Feltes N.A. \& Albanesi G.L. 2013. The Periodon and Paroistodus conodont biofacies in the lower member of the Las Aguaditas Formation (Middle Ordovician), Central Precordillera, Argentina. In: Albanesi G.L. \& Ortega G. (eds) Conodonts from the Andes International Conodont Symposium: 17-23. Asociación Paleontológica Argentina, Buenos Aires 3.

Feltes N.A., Albanesi G.L. \& Bergström S.M. 2016. Conodont biostratigraphy and global correlation of the Middle Darriwilian - Lower Sandbian Las Aguaditas Formation, Precordillera of San Juan, Argentina. Andean Geology 43: 60-85. https://doi.org/10.5027/andgeoV43n1-a04

Gower J.C. \& Hand D.J. 1996. Biplots. Chapman \& Hall, London.

Gradstein F.M., Ogg J.G., Schmitz M.D. \& Ogg G.M. (eds) 2020. Geologic Time Scale 2020. Elsevier, Amsterdam. https://doi.org/10.1127/nos/2020/0634

Gutiérrez-Marco J.C., Albanesi G.L., Sarmiento G.N. \& Carlotto V. 2008. An Early Ordovician (Floian) Conodont Fauna from the Eastern Cordillera of Perú (Central Andean Basin). Geologica Acta 6: 147160.

Hammer Ø. \& Harper, D.A.T. 2006. Paleontological Data Analysis. Blackwell Publishing, Ldt., Malden, Massachusetts. https://doi.org/10.1002/9780470750711

Hammer Ø., Harper D.A.T. \& Ryan P.D. 2001. PAST: paleontological statistics software package for education and data analysis. Palaeontologica Electronica 4: 1-9. 
Hints O., Viira V. \& Nõlvak J. 2012. Darriwilian (Middle Ordovician) conodont biostratigraphy in NW Estonia. Estonian Journal of Earth Sciences 61: 210-226. https://doi.org/10.3176/earth.2012.4.03

Ivantsov A.Yu. 2003. Ordovician trilobites of the subfamily Asaphinae of the Ladoga Glint. Paleontological Journal 37: S229-S337.

Jaanusson V. 1973. Aspects of carbonate sedimentation in the Ordovician of Baltoscandia. Lethaia 6: 11-34. https://doi.org/10.1111/j.1502-3931.1973.tb00871.x

Jeppsson L., Anehus R. \& Fredholm D. 1999. The optimal acetate buffered acetic acid technique for extracting phosphatic fossils. Journal of Paleontology 73: 957-965.

https://doi.org/10.1017/S0022336000040798

Lamansky W. 1905. Drevneyshie sloi siluriyskikh" otlozheniy Rossii / Die aeltesten silurischen Schichten Russlands (Etage B). Trudy Geologicheskago Komiteta, Novaya Seriya / Mémoires du Comité Géologique, Nouvelle Serie, Livr. 20: 1-203. [In Russian, with German summary.]

Landing E., Westrop S.R. \& Kim D.H. 2003. First Middle Ordovician biota from southern New Brunswick: stratigraphic and tectonic implications for the evolution of the Avalon continent. Canadian Journal of Earth Sciences 40: 715-730. https://doi.org/10.1139/E03-009

Lehnert D., Keller M. \& Bordonaro D. 1998. Early Ordovician conodonts from the southern Cuyania terrane (Mendoza Province, Argentina). In: H. Szaniawski (ed.) Proceedings of the Sixth European Conodont Symposium (ECOS VI). Palaeontologia Polonica 58: 47-65.

Lindskog A., Eriksson M.E., Rasmussen J.A., Dronov A. \& Rasmussen C.M.Ø. 2020. Middle Ordovician carbonate facies development, conodont biostratigraphy and faunal diversity patterns at the Lynna River, northwestern Russia. Estonian Journal of Earth Sciences 69: 37-61.

https://doi.org/10.3176/earth.2020.1.03

Lindström M. 1971. Lower Ordovician conodonts of Europe. Geological Society of America Memoirs 127: 21-61. https://doi.org/10.1130/MEM127-p21

Löfgren A. 1978. Arenigian and Llanvirnian conodonts from Jämtland, northern Sweden. Fossils and Strata 13: 1-129.

Löfgren A. 1994. Arenig (Lower Ordovician) conodonts and biozonation in the eastern Siljan district, central Sweden. Journal of Paleontology 68: 1350-1368. https://doi.org/10.1017/S0022336000034338

Löfgren A. 2000a. Conodont biozonation in the upper Arenig of Sweden. Geological Magazine 137: 53-65. https://doi.org/10.1017/S0016756800003484

Löfgren A. 2000b. Early to early Middle Ordovician conodont biostratigraphy of the Gillberga quarry, northern Öland, Sweden. GFF 122: 321-338. https://doi.org/10.1080/11035890001224321

Löfgren A. 2003. Conodont faunas with Lenodus variabilis in the upper Arenigian to lower Llanvirnian of Sweden. Acta Palaeontologica Polonica 48: 417-436.

Löfgren A. 2006. An Oistodus venustus-like conodont species from the Middle Ordovician of Baltoscandia. Paläontologische Zeitschrift 80: 12-21. https://doi.org/10.1007/BF02988394

Männil R.M. 1966. Istoriya razvitiya Baltiyskogo basseyna v ordovike [Evolution of the Baltic Basin during the Ordovician]. Eesti NSV Teaduste Akadeemia Geoloogia Institut, Tallinn. [In Russian with English summary.]

Marrama G. \& Kriwet J. 2017. Principal component and discriminant analyses as powerful tools to support taxonomic identification and their use for functional and phylogenetic signal detection of isolated fossil shark teeth. PLOS ONE 12: e0188806. https://doi.org/10.1371/journal.pone.0188806 
Mellgren J.I.S. \& Eriksson M.E. 2010. Untangling a Darriwilian (Middle Ordovician) palaeoecological event in Baltoscandia: conodont faunal changes across the 'Täljsten' interval. Earth and Environmental Science Transactions of the Royal Society of Edinburgh 100: 353-370. https://doi.org/10.1017/S1755691009009074

Mellgren J.I.S., Schmitz B., Ainsaar L., Kirsimäe K. \& Eriksson M.E. 2012. Conodont dating of the Middle Ordovician breccia cap-rock limestone on Osmussaar Island, northwestern Estonia. Estonian Journal of Earth Sciences 61: 133-148. https://doi.org/10.3176/earth.2012.3.01

Murdock D.J.E, Dong X.-P., Repetski J.E., Marone F., Stampanoni M. \& Donoghue P.C.J. 2013. The origin of conodonts and of vertebrate mineralized skeletons. Nature 502: 546-549.

https://doi.org/10.1038/nature12645

Nowlan G.S. 2002. Stratigraphy and conodont biostratigraphy of Upper Ordovician strata in the subsurface of Alberta, Canada. Special Papers in Palaeontology 67: 185-203.

Olgun O. 1987. Komponenten-Analyse und Conodonten-Stratigraphie der Orthoceratenkalksteine im Gebiet Falbygden, Västergötland, Mittelschweden. Sveriges Geologiska Undersökning, Ser. Ca 70: $1-78$.

Pander C.H. 1830. Beitrage zur Geognosie des Russischen Reiches. Karl Kray, St. Petersburg.

Pander C.H. 1856. Monographie der Fossil en Fische des Silurischen Systems der Russisch-Baltischen Gouvernements. Buchdruckerei der Kaiserlichen Akademie der Wissenschaften, St. Petersburg.

Pärnaste H., Bergström J. \& Zhou Z. 2013. High resolution trilobite stratigraphy of the Lower-Middle Ordovician Öland Series of Baltoscandia. Geological Magazine 150: 509-518.

https://doi.org/10.1017/S0016756812000908

Pearson K. 1901. On lines and planes of closest fit to systems of points in space. Philosophical Magazine, Series 6 2: 559-572. https://doi.org/10.1080/14786440109462720

Popov L.E. (ed.) 1997. WOGOGOB Excursion Guide: St. Petersburg, Russia, 1997. Uppsala University, Uppsala.

Purnell M.A., Donoghue P.C.J. \& Aldridge R.J. 2000. Orientation and anatomical notation in conodonts. Journal of Paleontology 74: 113-122.

https://doi.org/10.1666/0022-3360(2000)074<0113:OAANIC $>2.0 . C O ; 2$

Rasmussen C.M.Ø. \& Harper D.A.T. 2008. Resolving early Mid-Ordovician (Kundan) bioevents in the East Baltic based on brachiopods. Geobios 41: 533-542. https://doi.org/10.1016/j.geobios.2007.10.006

Rasmussen C.M.Ø., Ullmann C.V., Jakobsen K.G., Lindskog A., Hansen J., Hansen T., Eriksson M.E., Dronov A., Frei R., Korte C., Nielsen A.T. \& Harper D.A.T. 2016. Onset of main Phanerozoic marine radiation sparked by emerging Mid Ordovician icehouse. Scientific Reports 6: 18884.

https://doi.org/10.1038/srep18884

Rasmussen J.A. 1991. Conodont stratigraphy of the Lower Ordovician Huk Formation at Slemmestad, southern Norway. Norsk Geologisk Tidsskrift 71: 265-88.

Rasmussen J.A. 2001. Conodont biostratigraphy and taxonomy of the Ordovician shelf margin deposits in the Scandinavian Caledonides. Fossils and Strata 48: 1-180.

Rasmussen J.A. \& Stouge S. 2018. Baltoscandian conodont biofacies fluctuations and their link to Middle Ordovician (Darriwilian) global cooling. Palaeontology 61: 391-416.

https://doi.org/10.1111/pala.12348 
Raymond P.E. 1916. Expedition to the Baltic provinces of Russia and Scandinavia. Part I. The correlation of the Ordovician strata of the Baltic Basin with those of eastern North America. Bulletin of the Museum of Comparative Zoology 56: 179-286.

Schmidt F. 1882. On the Silurian (and Cambrian) strata of the Baltic provinces of Russia, as compared with those of Scandinavia and the British Isles. Quarterly Journal for the Geological Society 38: 514 536. https://doi.org/10.1144/GSL.JGS.1882.038.01-04.51

Sergeeva S.P. 1962. [Stratigraphic dispersion of conodonts in the Lower Ordovician of the Leningrad province.] Doklady Akademii Nauk SSSR 146: 1393-1395. [In Russian.]

Sergeeva S.P. 1963. [Conodonts from the Lower Ordovician in the Leningrad region.] Paleontologicheshij Zhurnal 1963 (2): 93-108. [In Russian.]

Sergeeva S.P. 1974. [Some new conodonts from Ordovician deposits of the Leningrad region.] Paleontologicheskii Sbornik 2 (11): 79-84. [In Russian.]

Serra F., Feltes N.A., Albanesi G.L. \& Goldman D. 2019. High-resolution conodont biostratigraphy from the Darriwilian Stage (Middle Ordovician) of the Argentine Precordillera and biodiversity analyses: a CONOP9 approach. Lethaia 52: 188-203. https://doi.org/10.1111/let.12306

Smith M.P., Donoghue P.C.J. \& Repetski J.E. 2005. The apparatus composition and architecture of Cordylodus Pander - Concepts of homology in primitive conodonts. Bulletin of American Paleontology 369: 19-33.

Stauffer C.R. 1935. Conodonts of the Glenwood beds. Geological Society of America Bulletin 46: 125168. https://doi.org/10.1130/GSAB-46-125

Stouge S. 1984. Conodonts of the Middle Ordovician Table Head Formation, western Nemoundland. Fossils and Strata 16: 1-145.

Stouge S. \& Bagnoli G. 1990. Lower Ordovician (Volkhovian-Kundan) conodonts from Hagudden, northern Öland, Sweden. Palaeontographica Italica 77: 1-54.

Sweet W.C. 1981. Macromorphology of elements and apparatuses. In: Robison R.A. (ed.) Treatise on Invertebrate Paleontology, Part W, Miscellanea, Suppl. 2, Conodonta: 5-20. Geological Society of America and the University of Kansas Press, Lawrence.

Sweet W.C. 1988. The Conodonta: morphology, taxonomy, paleoecology, and evolutionary history of a long-extinct animal phylum. Oxford Monographs on Geology and Geophysics 10: 1-212.

Tolmacheva T.Yu. 2001. Conodont Biostratigraphy and Diversity in the Lower-Middle Ordovician of Eastern Baltoscandia (St. Petersburg Region, Russia) and Kazakhstan. PhD Thesis, comprehensive summary. Uppsala University, Sweden.

Tolmacheva T.Yu., Koren T.N., Holmer L.E., Popov L.E. \& Raevskaya E. 2001. The Hunneberg Stage (Ordovician) in the area east of St. Petersburg: north-western Russia. Paläontologische Zeitschrift 74: 543-561. https://doi.org/10.1007/BF02988161

Tolmacheva T.Yu., Fedorov P. \& Egerquist E. 2003a. Conodonts and brachiopods from the Volkhov Stage (Lower Ordovician) microbial mud mound at Putilovo Quarry, north-western Russia. Bulletin of the Geological Society of Denmark 50: 63-74. https://doi.org/10.37570/bgsd-2003-50-05

Tolmacheva T.Yu., Egerquist E., Meidla T., Tinn O. \& Holmer L. 2003b. Faunal composition and dynamics in unconsolidated sediments: a case study from the Middle Ordovician of the East Baltic. Geological Magazine 140: 31-44. https://doi.org/10.1017/S001675680200701X 
Tolmacheva T.Yu., Zaitsev A.V. \& Alekseev A.S. 2013. Middle and Upper Ordovician conodonts of the Moscow Syneclise: new data on stratigraphy of the borehole Gavrilov Yam-1 section. Stratigrafiya. Geologicheskaya Korrelyatsiya 21: 52-77. https://doi.org/10.1134/S0869593813040096

Turner S., Burrow C.J., Schultze H.-P., Blieck A., Reif W.-E., Rexroad C.B., Bultynck P. \& Nowlan G.S. 2010. False teeth: conodont-vertebrate phylogenetic relationships revisited. Geodiversitas 32: 545-594. https://doi.org/10.5252/g2010n4a1

Van Wamel W.A. 1974. Conodont biostratigraphy of the Upper Cambrian and Lower Ordovician of north-western bland, south-eastern Sweden. Utrecht Micropaleontological Bulletins 10: 1-126.

Viira V., Löfgren A., Mägi S. \& Wickström J. 2001. An Early to Middle Ordovician succession of conodont faunas at Mäekalda, northern Estonia. Geological Magazine 138: 699-718.

https://doi.org/10.1017/S0016756801005945

Webers G.F. 1966. The Middle and Upper Ordovician Conodont Faunas of Minnesota. Minnesota Geological Survey, Special Publication 4: 1-123.

Wu R.-C., Calner M. \& Lehnert O. 2017. Integrated conodont biostratigraphy and carbon isotope chemostratigraphy in the Lower-Middle Ordovician of southern Sweden reveals a complete record of the MDICE. Geological Magazine 154: 334-353. https://doi.org/10.1017/S0016756816000017

Wu R.-C., Calner M., Lehnert O., Lindskog A. \& Joachimski M. 2018. Conodont biostratigraphy and carbon isotope stratigraphy of the Middle Ordovician (Darriwilian) Komstad Limestone, southern Sweden. GFF 140: 44-54. https://doi.org/10.1080/11035897.2018.1435561

Wu R.-C., Stouge S., Zhang Y. \& Wang Z. 2020. Biostratigraphy and palaeoecology of Middle and Late Ordovician conodonts from the Hulo and Yenwashan formations, western Zhejiang, south-eastern China. Geological Journal 55: 2995-3009. https://doi.org/10.1002/gj.3560

Zhang J. 1998. Conodonts from the Guniutan Formation (Llanvirnian) in Hubei and Hunan Provinces, south-central China. Stockholm Contributions in Geology 46: 1-161.

Zhen Y.Y. 2020. Revision of the Darriwilian (Middle Ordovician) conodonts documented by Watson (1988) from subsurface Canning Basin, Western Australia. Alcheringa 44: 217-252.

https://doi.org/10.1080/03115518.2020.1737227

Zhen Y.Y. \& Percival I.G. 2004. Middle Ordovician (Darriwilian) conodonts from allochthonous limestones in the Oakdale Formation of central New South Wales. Alcheringa 28: 77-111.

https://doi.org/10.1080/03115510408619276

Zhen Y.Y., Wang Z.H., Zhang Y.D., Bergström S.M., Percival I.G. \& Chen J.F. 2011. Middle to Late Ordovician (Darriwilian-Sandbian) conodonts from the Dawangou Section, Kalpin area of the Tarim Basin, northwestern China. Records of the Australian Museum 63: 203-266.

https://doi.org/10.3853/j.0067-1975.63.2011.1586

Manuscript received: 14 March 2021

Manuscript accepted: 1 September 2021

Published on: 8 October 2021

Topic editor: Christian de Muizon

Desk editor: Pepe Fernández

Printed versions of all papers are also deposited in the libraries of the institutes that are members of the EJT consortium: Muséum national d'histoire naturelle, Paris, France; Meise Botanic Garden, Belgium; 
Royal Museum for Central Africa, Tervuren, Belgium; Royal Belgian Institute of Natural Sciences, Brussels, Belgium; Natural History Museum of Denmark, Copenhagen, Denmark; Naturalis Biodiversity Center, Leiden, the Netherlands; Museo Nacional de Ciencias Naturales-CSIC, Madrid, Spain; Real Jardín Botánico de Madrid CSIC, Spain; Zoological Research Museum Alexander Koenig, Bonn, Germany; National Museum, Prague, Czech Republic. 